\title{
Rigorously Valuing the Potential Coastal Hazard Risk Reduction Provided by Coral Reef Restoration in Florida and Puerto Rico
}

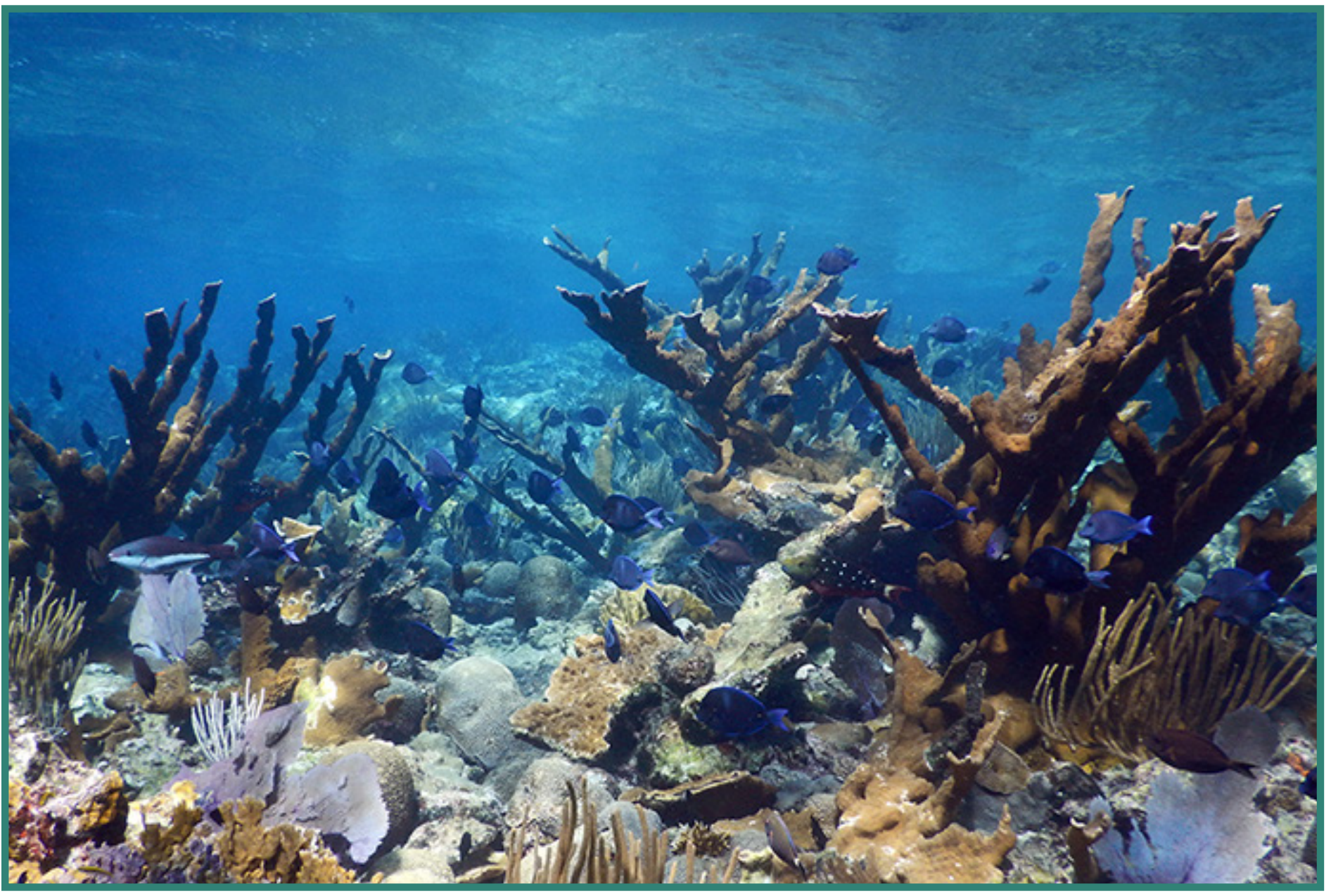

Open-File Report 2021-1054 
Cover. U.S. Geological Survey underwater photograph showing a healthy, thriving coral reef in Buck Island Reef National Monument, U.S. Virgin Islands. 


\section{Rigorously Valuing the Potential Coastal Hazard Risk Reduction Provided by Coral Reef Restoration in Florida and Puerto Rico}

By Curt D. Storlazzi, Borja G. Reguero, Kristen A. Cumming, Aaron D. Cole, James B. Shope, Camila Gaido L., T. Shay Viehman, Barry A. Nickel, and Michael W. Beck

Open-File Report 2021-1054 


\section{U.S. Geological Survey, Reston, Virginia: 2021}

For more information on the USGS — the Federal source for science about the Earth, its natural and living resources, natural hazards, and the environment-visit https://www.usgs.gov or call 1-888-ASK-USGS.

For an overview of USGS information products, including maps, imagery, and publications, visit https://store.usgs.gov.

Any use of trade, firm, or product names is for descriptive purposes only and does not imply endorsement by the U.S. Government.

Although this information product, for the most part, is in the public domain, it also may contain copyrighted materials as noted in the text. Permission to reproduce copyrighted items must be secured from the copyright owner.

Suggested citation:

Storlazzi, C.D., Reguero, B.G., Cumming, K.A., Cole, A.D., Shope, J.B., Gaido L., C., Viehman, T.S., Nickel, B.A., and Beck, M.W., 2021, Rigorously valuing the coastal hazard risks reduction provided by potential coral reef restoration in Florida and Puerto Rico: U.S. Geological Survey Open-File Report 2021-1054, 35 p., https://doi.org/10.3133/ ofr20211054.

Associated data for this publication:

Cumming, K.A., Cole, A.D., Storlazzi, C.D., Reguero, B.G., Shope, J.B., Gaido L., C., Viehman, T.S., Nickel, B.A., and Beck, M.W., 2021, Projected flooding extents and depths based on 10-, 50-, 100-, and 500-year wave-energy return periods for the State of Florida, the Commonwealth of Puerto Rico, and the Territory of the U.S. Virgin Islands for current and potentially restored coral reefs: U.S. Geological Survey data release, https://doi.org/10.5066/P9ZOKZR9.

ISSN 2331-1258 (online) 


\section{Contents}

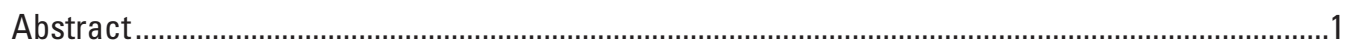

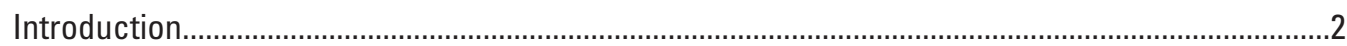

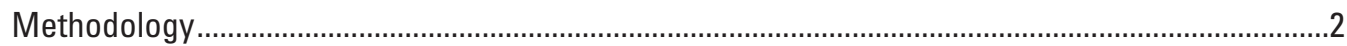

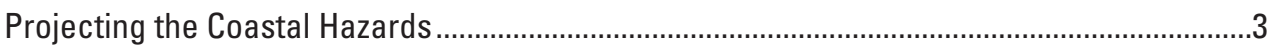

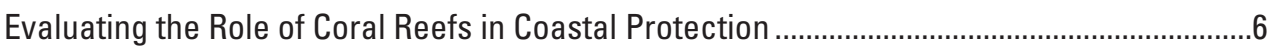

Reef Restoration Scenarios ........................................................................................

Evaluating the Role of Potential Coral Reef Restoration in Increasing Coastal Protection .....8

Quantifying the Social and Economic Benefits of Potential Coral Reef Restoration ................8

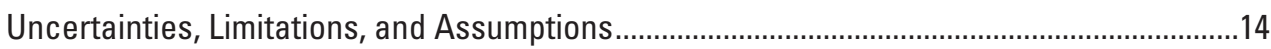

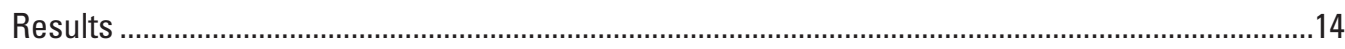

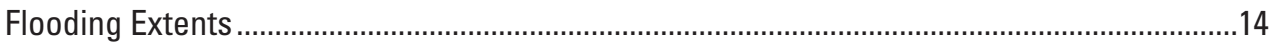

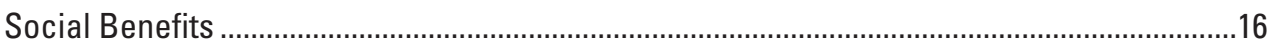

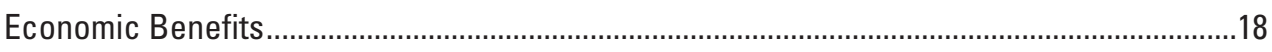

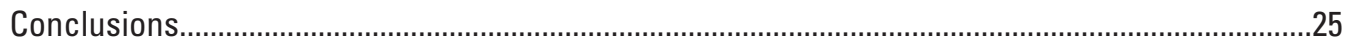

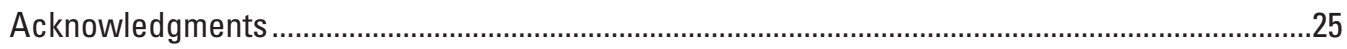

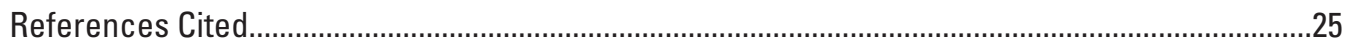

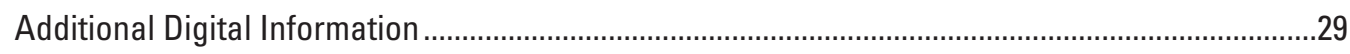

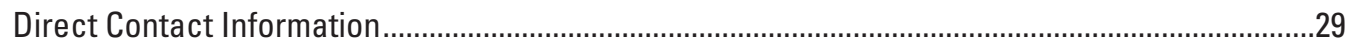

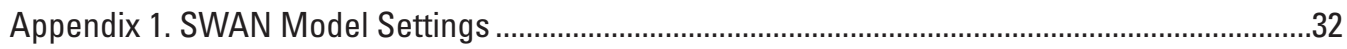

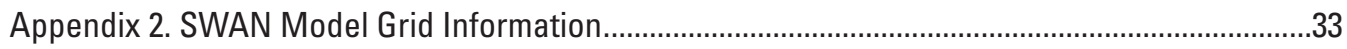

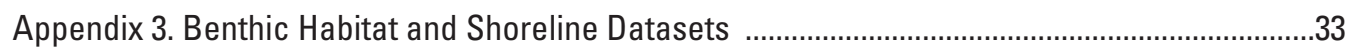

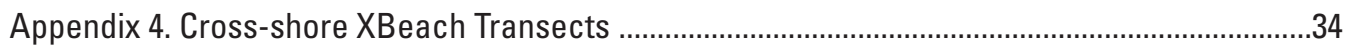

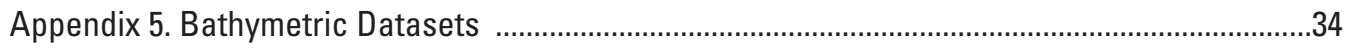

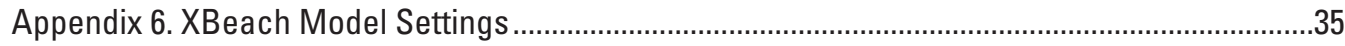

\section{Figures}

1. Map indicating the location of the study areas in Florida and Puerto Rico .......................3

2. Schematic diagram that shows the methodology used to evaluate the increase in coastal flooding hazard risk owing to hurricane-induced damage to coral reefs ............4

3. Maps showing output examples of the Simulating Waves Nearshore model and how one of the 500 wave conditions were dynamically downscaled to the 200-meter $(\mathrm{m})$ grid scale offshore northeastern Puerto Rico …………………………............................

4. Example map showing the coral extent, coral coverage and locations of theoretical coral reef restorations offshore Key West, Florida.........................................................

5. Plots of example Puerto Rico topographic-bathymetric cross-sections and XBeach model wave-driven total water levels.

6. Map showing example 100-year floodplains for both with and without the E25, S05, and S25 coral reef restoration scenarios on Isla Verde, San Juan, Puerto Rico .............9

7. Maps showing example 10-meter resolution flood depths for various storm recurrence intervals on Key West, Florida. 
8. Map showing the distribution of people protected from coastal flooding from the S05 coral reef restoration scenario for the 100-year storm eastern San Juan, Puerto Rico

9. Map showing the value of infrastructure protected from coastal flooding from the $\mathrm{S} 05$ coral reef restoration scenario for the 100 -year storm on eastern San Juan, Puerto Rico

10. Example plots showing damage curves both with and without the coral reef restoration scenarios in Puerto Rico.

\section{Tables}

1. Wave and current friction coefficients for different percentages of coral cover as determined from benthic habitat maps following Storlazzi and others (2019)

2. Gross domestic product per person by island or region

3. Spatial extent, in square kilometers, of area protected from coastal flooding because of the E25 coral reef restoration scenario for different return-interval storms by region

4. Spatial extent, in square kilometers, of area protected from coastal flooding because of the $\$ 25$ coral reef restoration scenario for different return-interval storms by region

5. Spatial extent, in square kilometers, of area protected from coastal flooding because of the $\mathrm{S} 05$ coral reef restoration scenario for different return-interval storms by region

6. Total number of people protected from coastal flooding because of the E25 coral reef restoration scenario for different return-interval storms by region.

7. Total number of people protected from coastal flooding because of the $\$ 25$ coral reef restoration scenario for different return-interval storms by region

8. Total number of people protected from coastal flooding because of the $\mathrm{S} 05$ coral reef restoration scenario for different return-interval storms by region.....

9. Total number of buildings (all infrastructure types) protected from coastal flooding because of the E25 coral reef restoration scenario for different return-interval storms by region

10. Total number of buildings (all infrastructure types) protected from coastal flooding because of the $\mathbf{S} 25$ coral reef restoration scenario for different return-interval storms by region

11. Total number of buildings (all infrastructure types) protected from coastal flooding because of the $\mathrm{S} 05$ coral reef restoration scenario for different return-interval storms by region

12. Total value of buildings protected from coastal flooding because of the E25 coral reef restoration scenario for different return-interval storms by region

13. Total value of buildings (all infrastructure types) protected from coastal flooding because of the $\mathbf{S} 25$ coral reef restoration scenario for different return-interval storms by region 
14. Total value of buildings protected from coastal flooding because of the S05 coral reef restoration scenario for different return-interval storms by region..

15. Total value of economic activity, in 2010 U.S. dollars, protected from coastal flooding because of the E25 coral reef restoration scenario for different return-interval storms by region.

16. Total value of economic activity, in 2010 U.S. dollars, protected from coastal flooding because of the $S 25$ coral reef restoration scenario for different return-interval storms by region.

17. Total value of economic activity, in 2010 U.S. dollars, protected from coastal flooding because of the $\mathrm{S} 05$ coral reef restoration scenario for different return-interval storms by region.

18. Annual value protected from coastal flooding because of the E25 coral reef restoration scenario by region.

19. Annual value, in number of people or 2010 U.S. dollars, protected from coastal flooding because of the $S 25$ coral reef restoration scenario.

20. Annual value, in number of people or 2010 U.S. dollars, protected from coastal flooding because of the S05 coral reef restoration scenario. 


\section{Conversion Factors}

U.S. customary units to International System of Units

\begin{tabular}{|c|c|c|}
\hline Multiply & By & To obtain \\
\hline \multicolumn{3}{|c|}{ Length } \\
\hline foot $(\mathrm{ft})$ & 0.3048 & meter (m) \\
\hline mile (mi) & 1.609 & kilometer (km) \\
\hline yard (yd) & 0.9144 & meter (m) \\
\hline \multicolumn{3}{|c|}{ Area } \\
\hline square foot $\left(\mathrm{ft}^{2}\right)$ & 0.09290 & square meter $\left(\mathrm{m}^{2}\right)$ \\
\hline square mile $\left(\mathrm{mi}^{2}\right)$ & 259.0 & hectare (ha) \\
\hline square mile $\left(\mathrm{mi}^{2}\right)$ & 2.590 & square kilometer $\left(\mathrm{km}^{2}\right)$ \\
\hline
\end{tabular}

\section{Abbreviations}

$\begin{array}{ll}\text { DSAS } & \text { Digital Shoreline Analysis System } \\ \text { EAB } & \text { Expected Annual Benefit } \\ \text { EAD } & \text { Expected Annual Damage } \\ \text { FEMA } & \text { Federal Emergency Management Agency } \\ \text { GEV } & \text { General Extreme Value } \\ \text { GOW } & \text { Global Ocean Wave } \\ \text { GDP } & \text { Gross Domestic Product } \\ \text { HAZUS } & \text { Federal Emergency Management Agency database } \\ \text { NOAA } & \text { National Oceanic and Atmospheric Administration } \\ \text { PAEK } & \text { Polynomial Approximation with Exponential Kernal } \\ \text { SBC } & \text { Smoothed Baseline Cast } \\ \text { SWAN } & \text { Deltares 2-dimensional short wave model } \\ \text { UCSC } & \text { University of California at Santa Cruz } \\ \text { USACE } & \text { United State Army Corps of Engineers } \\ \text { USGS } & \text { United States Geological Survey } \\ \text { XBeach } & \text { Deltares 2-dimensional short and long wave and flow model }\end{array}$

\section{Variables}

$C_{f} \quad$ Friction coefficient for currents and infragravity wave friction

$f_{w} \quad$ Friction coefficient for incident waves 


\title{
Rigorously Valuing the Potential Coastal Hazard Risk Reduction Provided by Coral Reef Restoration in Florida and Puerto Rico
}

\author{
By Curt D. Storlazzi, ${ }^{1}$ Borja G. Reguero, ${ }^{2}$ Kristen A. Cumming, ${ }^{1}$ Aaron D. Cole, ${ }^{2}$ James B. Shope, ${ }^{2}$ \\ Camila Gaido L., ${ }^{2}$ Shay Viehman, ${ }^{3}$ Barry A. Nickel, ${ }^{2}$ and Michael W. Beck ${ }^{2}$
}

\section{Abstract}

The restoration of coastal habitats, particularly coral reefs, can reduce risks by decreasing the exposure of coastal communities to flooding hazards. In the United States, the protective services provided by coral reefs were recently assessed in social and economic terms, with the annual protection provided by U.S. coral reefs off the coasts of the State of Florida and the Commonwealth of Puerto Rico estimated to be more than 9,800 people and $\$ 859$ million (2010 U.S. dollars). Hurricanes Irma and Maria in 2017 caused widespread damage to coral reefs in the State of Florida and the Commonwealth of Puerto Rico. Here we combine engineering, ecologic, geospatial, social, and economic data and tools to provide a rigorous valuation of where potential coral reef restoration could decrease the hazard faced by Florida and Puerto Rico's reef-fronted coastal communities. The three restoration scenarios considered: (1) Ecological restoration, 'E25', which assumes planting 0.25-meter (m)-high corals on a (cross-shore) 25-m-wide reef; (2) Structural plus ecological, 'S25', which assumes emplacing a 1.00-m high structure with $0.25-\mathrm{m}$ high corals on top on a $25 \mathrm{~m}$ wide reef; and (3) structural plus ecological, 'S05', which assumes emplacing a $1.00-\mathrm{m}$ high structure with $0.25-\mathrm{m}$ high corals on top on a $5 \mathrm{~m}$ wide reef. Planted corals are assumed to increase hydrodynamic roughness, thereby dissipating incident wave energy and decreasing flooding potential. We used a standardized approach to 'place' potential restoration projects throughout the whole (linear) extent of reefs bordering Florida and Puerto Rico to identify where coral reef restoration could be useful for meeting flood reduction benefits. We always sited potential restoration projects within the existing distribution of reefs even though many sites were far (kilometers [km]) offshore and some sites were relatively deep (up to $7 \mathrm{~m}$ depth). We followed risk-based valuation approaches to map flood zones at 10-square-meter resolution along all $980 \mathrm{~km}$ of

${ }^{1}$ U.S. Geological Survey.

${ }^{2}$ University of California at Santa Cruz.

${ }^{3}$ National Oceanic and Atmospheric Administration.
Florida and Puerto's Rico reef-lined shorelines for the three potential coral reef restoration scenarios and compare them to the flood zones without coral reef restoration. We quantified the potential coastal flood risk reduction provided by coral reef restoration using the latest information from the U.S. Census Bureau, Federal Emergency Management Agency, and Bureau of Economic Analysis for return-interval storm events. Using the damages associated with each storm probability, we also calculate the change in annual expected damages, a measure of the annual protection gained because of coral reef restoration. We found that the benefits of reef restoration off Florida and Puerto Rico are spatially highly variable. In most areas, we found little or no benefit from reef restoration (for example, restoration sites were far offshore or deep). However, there were a number of key areas where reef restoration could have substantial benefits for flood risk reduction. In particular, we estimated the protection gained by Florida and Puerto Rico's coral reefs from coral reef restoration to result in:

- Avoided flooding to more than 5.6 square kilometers (2.16 square miles) of land annually;

- Avoided flooding affecting more than 3,100 people annually;

- Avoided direct damages of more than \$124.2 million to more than 890 buildings annually; and

- Avoided indirect damages to more \$148.7 million in economic activity owing to housing and business damage annually.

Thus, the annual value of flood risk reduction provided by potential coral reef restoration in Florida and Puerto Rico is more than 3,100 people and \$272.9 million (2010 U.S. dollars) in economic activity. These data provide stakeholders and decision makers with a spatially explicit, rigorous valuation of how, where, and when potential coral reef restoration in Florida and Puerto Rico can increase critical coastal storm flood reduction benefits. These results help identify areas where reef management, recovery, and restoration could potentially help reduce the risk to, and increase the resiliency of, Florida and Puerto Rico's coastal communities. 


\section{Introduction}

Coastal flooding and erosion from extreme weather events affect thousands of vulnerable coastal communities. The impacts of coastal flooding are predicted to worsen during this century because of population growth and climate change (Hallegatte and others, 2013; Hinkel and others, 2014; Reguero and others, 2015, 2018; Storlazzi and others, 2018). There is an urgent need to develop better risk reduction and adaptation strategies to reduce coastal flooding and associated hazards (Hinkel and others, 2014; National Research Council, 2014). For example, the United States spends, on average, $\$ 500$ million per year mitigating such coastal hazards (Federal Emergency Management Agency, 2016a).

Coral reefs, in particular, can substantially reduce coastal flooding and erosion by dissipating up to 97 percent of incident wave energy (Ferrario and others, 2014). Reefs function like low-crested structures such as breakwaters, with hydrodynamic behavior well characterized by coastal engineering models (Hoeke and others, 2011; Taebi and Pattiaratchi, 2014; Reguero and others, 2018). Recently, a process-based, high-resolution, non-linear model of coastal protection benefits provided by corals reefs that mapped these natural defense benefits at a resolution relevant to management scales, and provided a framework to rigorously value the people and property protected by coral reefs under numerous current and future climates, was developed for all populated U.S. coral reef-lined coasts (Storlazzi and others, 2019).

Hurricane Irma struck the State of Florida as a Category 4 hurricane on September 10, 2017, (Cangialosi and others, 2018), causing dozens of deaths and more than $\$ 50$ billion in damage, and thus was the costliest storm in the history of the state. Ten days later, Hurricane Maria made landfall on the south coast of the Commonwealth of Puerto Rico as a Category 4 hurricane on September 20, 2017 (Pasch and others, 2018). Hurricane Maria caused thousands of deaths, more than $\$ 90$ billion in damage, and the biggest electrical blackout in U.S. history (Federal Communications Commission, 2018).

Because of the hazard risk reduction provided by coral reefs (Reguero and others, 2018 Storlazzi and others, 2019), reef restoration is increasingly being suggested to reduce the flood risk to, and increase the resiliency of, tropical coastal communities (Beck and Lange, 2016). Common objectives of coral reef restoration are to rebuild habitat and (or) coral populations that have been lost or damaged because of storms or anthropogenic activities, or improve resilience to future disturbances. Restoration is typically either purely ecological or conducted in combination with structure emplacement to enhance the reef morphology. Ecological (or green) restoration usually involves increasing the number of living corals on the reef in areas where solid benthic substrate and vertical structure is already available (Shaver and Silliman. 2017; Boström-Einarsson and others, 2020). Such type of restoration is generally achieved through methods such as collecting and rehabilitating naturally broken coral fragments, propagating coral colonies, or transplanting living coral colonies (Bayraktarov and others, 2019). The general goal of ecological restoration is to repopulate corals in areas where populations have been diminished or lost in a manner that allows self-perpetuation and attraction of the species that are essential to ecological processes on reefs (Lirman and Schopmeyer. 2016; Ladd and others, 2018). Structural or "gray" restoration generally involves development of artificial reefs using existing rocks/dead coral heads, or the deployment of constructed metal or concrete forms. The goal is to increase the amount of reef structure and habitat available for the corals and other reef organisms to grow on. Structural restoration is required in areas were the reef has been lost owing to longterm bioerosion of the reef or physical damage such as a vessel grounding. These structures can then either be reseeded by natural coral recruitment, or more commonly 'seeded' with coral transplants to facilitate and speed development, which is a "gray-green" hybrid form of restoration.

As part of the Federal government's recovery and restoration efforts following these natural disasters, the National Oceanic and Atmospheric Administration's (NOAA) Coral Restoration Center and The Nature Conservancy (TNC), two organizations who conduct coral reef restoration efforts, approached the Federal Emergency Management Agency (FEMA) to discuss the possibility of implementing large-scale coral reef restoration in the areas impacted by the hurricanes. FEMA, which is required to conduct benefit cost analyses (BCAs) to justify post-disaster funding, would need such BCAs to release funding for coral reef restoration aimed at coastal hazard risk reduction. To address this need, the U.S. Geological Survey (USGS) worked with the University of California at Santa Cruz (UCSC) and NOAA to assess and quantify, in social and economic terms, how the potential restoration of coral reefs off Florida and Puerto Rico could reduce the threats to, and increase the resiliency of, their coastal communities.

\section{Methodology}

Engineering, ecologic, social, and economic data and tools were combined to provide a quantitative valuation of the increase in coastal protection benefits provided by potential coral reef restoration off the State of Florida and the Commonwealth of Puerto Rico (fig. 1). The goal of this effort was to identify how, where, and when coral reef restoration could potentially increase the coastal flood reduction benefits socially and economically. This analysis follows a risk quantification valuation framework to estimate the risk reduction benefits from coral reefs and provide annual expected benefits in social and economic terms (Storlazzi and others, 2019). This study represents the first unique and innovative effort to rigorously quantify the decrease in coastal hazard risk resulting from coral reef restoration, based on high-resolution flooding modeling and state of art damage modeling and calculations based on approaches used by used by the FEMA and the U.S. Army Corps of Engineers (USACE). The methods follow a sequence of steps (fig. 2) derived from Storlazzi and others (2019) that integrate 
physics-based hydrodynamic modeling, quantitative geospatial modeling, and social and economic analyses to quantify the hazard, the role of coral reef restoration in decreasing coastal flooding, and the economic and social consequences.

\section{Projecting the Coastal Hazards}

Sixty one years (1948-2008) of validated long-term, hourly hindcast deep-water wave data were extracted from

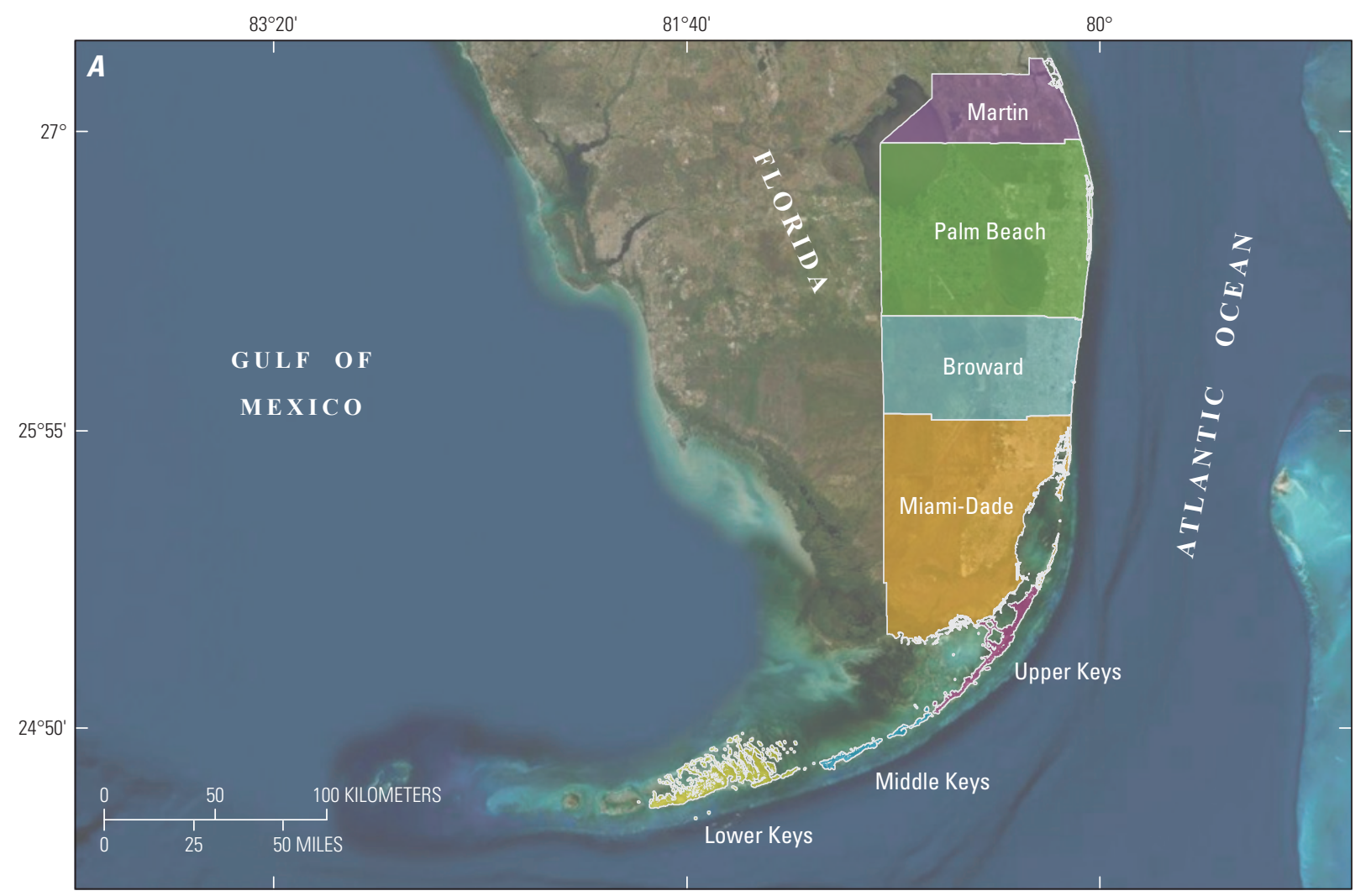

$66^{\circ} 57$

$66^{\circ} 6^{\prime}$

$65^{\circ} 15^{\prime}$

B

ATLANTIC OCEAN

$18^{\circ} 40^{\prime}$

18

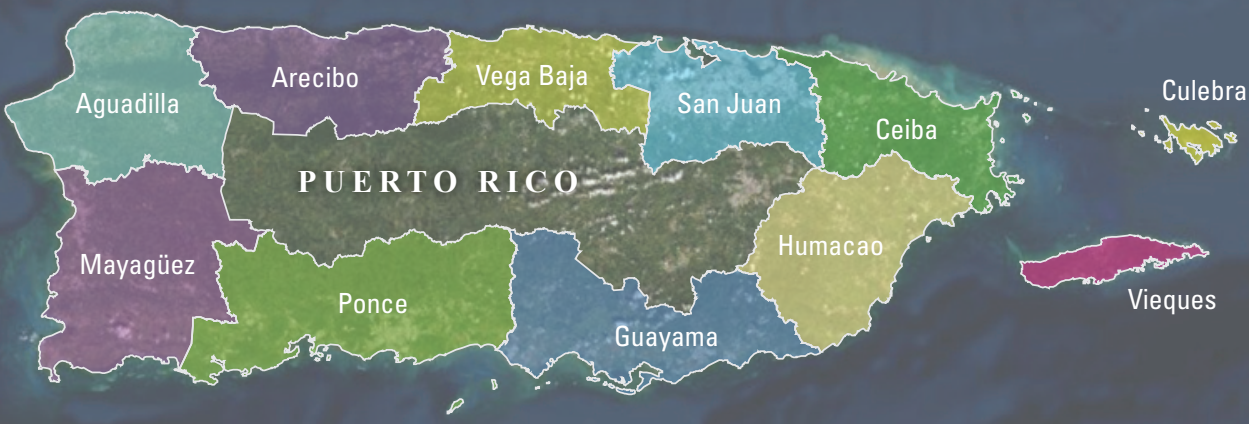

C A R I B B E A N S E A

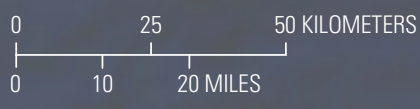

Figure 1. Map indicating the location of the study areas in Florida $(A)$ and Puerto Rico $(B)$. 


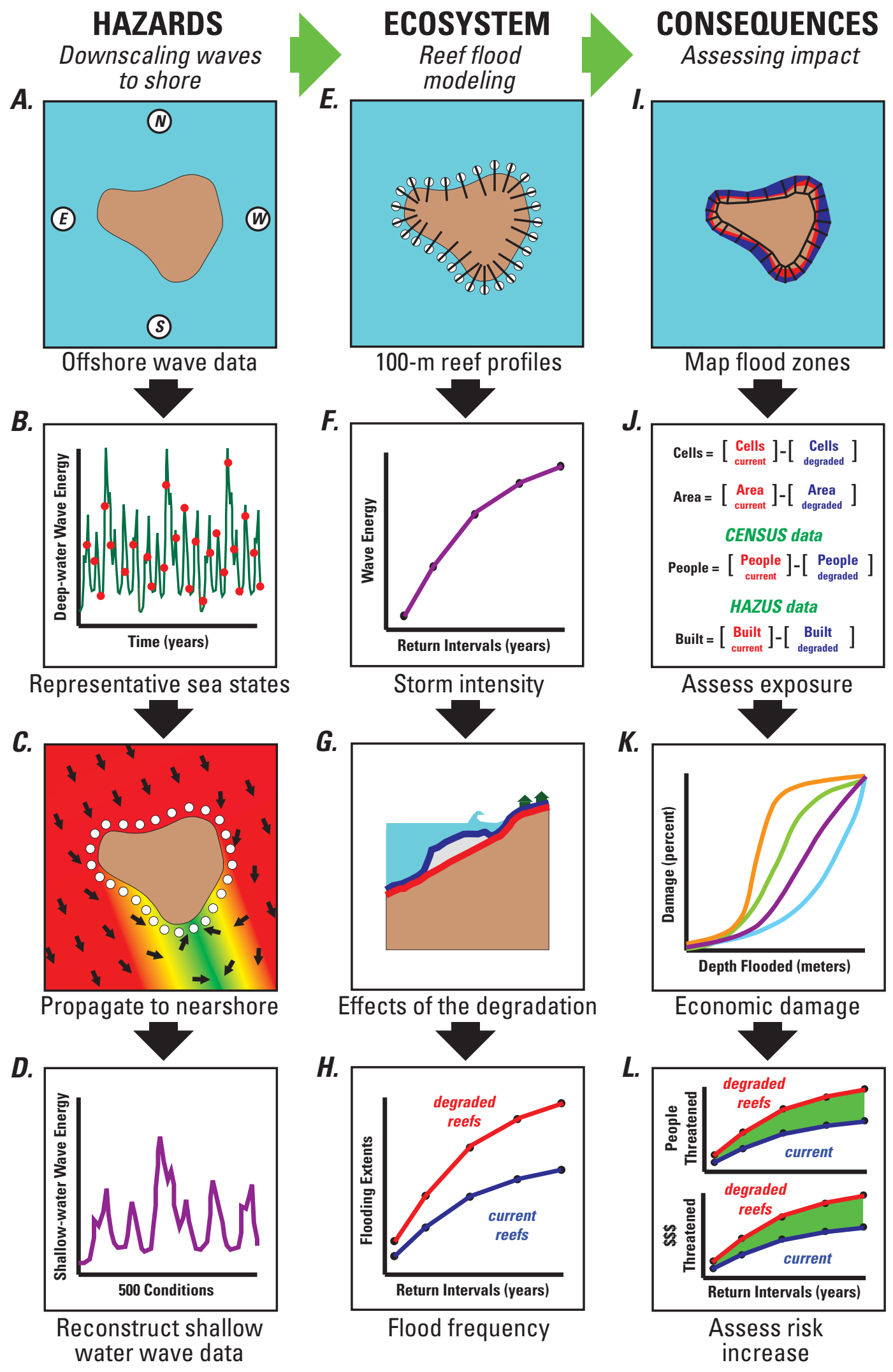

Figure 2. Schematic diagram that shows the methodology used to evaluate the increase in coastal flooding hazard risk owing to hurricane-induced damage to coral reefs. Modified after Storlazzi and others (2019). Each step is described in more detail in the methodology section. m, meter. 
the Global Ocean Wave (GOW) database (Reguero and others, 2012) for the populated, reef-lined coastal areas of Florida and Puerto Rico (fig. 2A). Following the methodology of Camus and others (2011), we propagated more than half a million hourly data on wave climate parameters to the nearshore shore using a hybrid downscaling approach. The offshore wave climate data were synthesized into 500 combinations of sea states (wave height, wave periods, and wave directions) that best represented the range of conditions from the GOW database (fig. $2 B$ ). These selected sea states were then propagated to the coast using the physics-based Simulating Waves Nearshore (SWAN) spectral wave model (Booij and others, 1999; Ris and others, 1999; Delft University of Technology, 2016), which simulates wave transformations nearshore by solving the spectral action balance equation (fig. 2C). Wave propagation around reef-lined islands has been accurately simulated using SWAN (Hoeke and others, 2011; Taebi and Pattiaratchi, 2014; Storlazzi and others, 2015). Standard SWAN settings were used (for example, Hoeke and others, 2011; Storlazzi and others, 2015), except that the directional spectrum was refined to 5 -degree bins (72 total) to better simulate refraction and diffraction in and amongst islands (appendix 1).

To accurately model from the scale of the island groups or large sections of coastline (order of 10s of kilometers $[\mathrm{km}]$ ) down to management scales (order of 100s of meters $[\mathrm{m}]$ ), a series of two dynamically downscaled nested, rectilinear grids were used. The coarse (1-km resolution) SWAN grids provided spatially varying boundary conditions for finer-scale (200-m resolution) SWAN grids (fig. 3). The bathymetry for the SWAN grids were generated by grid-cell averaging of various topobathymetric digital elevation (DEM)
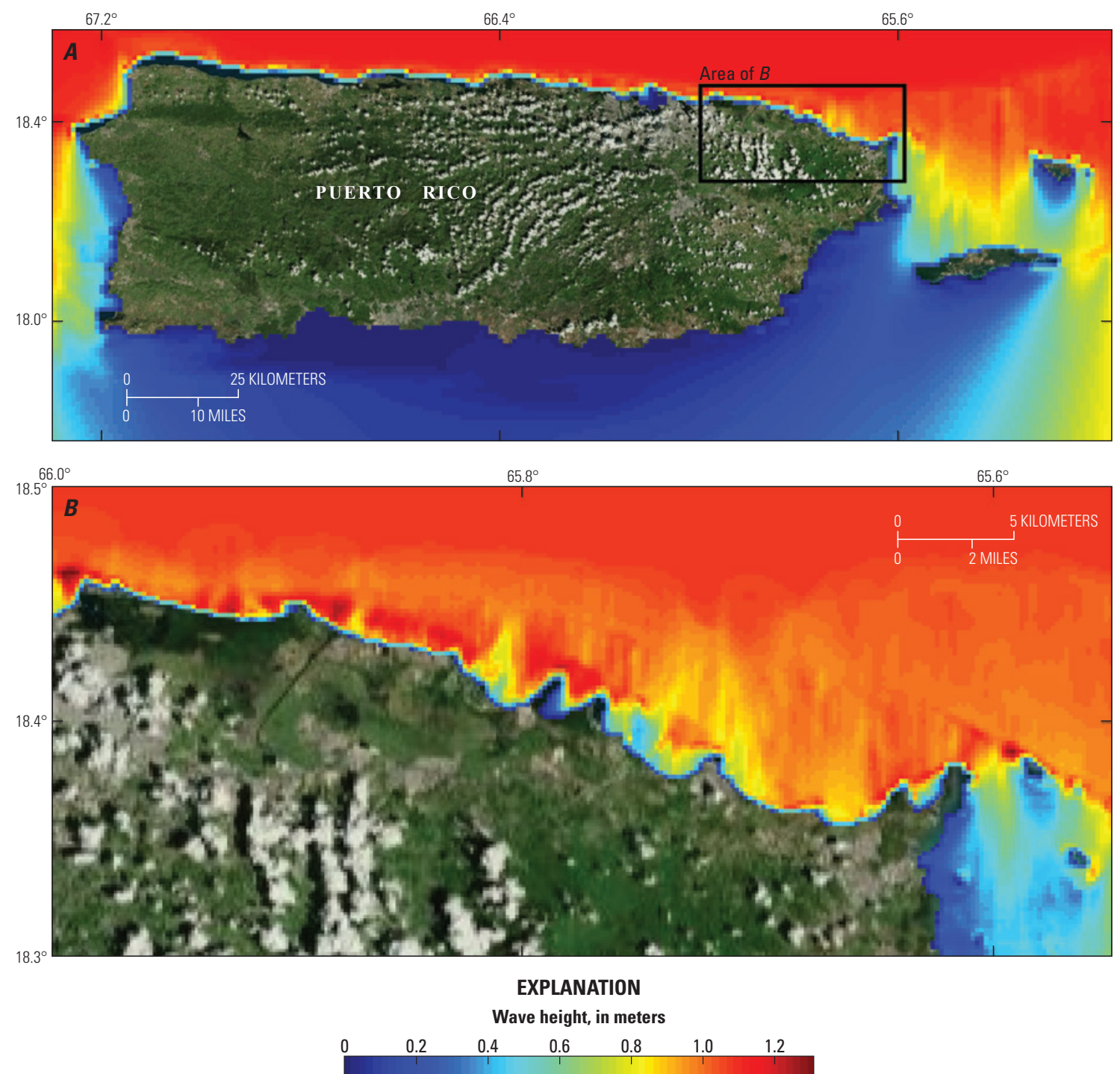

Figure 3. Maps showing output examples of the Simulating Waves Nearshore (SWAN) model and how one of the 500 wave conditions were dynamically downscaled to the 200-meter $(\mathrm{m})$ grid scale offshore northeastern Puerto Rico. $A$. The 1-kilometer $(\mathrm{km})$ resolution Puerto Rico model. $B$, The 200-m resolution northeastern Puerto Rico model embedded in the 1-km Puerto Rico model. Colors indicate significant wave height, in meters. The black rectangle in subplot $A$ indicates the extent of the area in subplot $B$. 
models (appendix 2). The propagated 500 shallow-water wave conditions from the finest SWAN grids were extracted at 100-m intervals along the coastline, at a water depth of $30 \mathrm{~m}$ (fig. 2D), and then reconstructed into hourly time series using multidimensional interpolation techniques (Camus and others, 2011).

\section{Evaluating the Role of Coral Reefs in Coastal Protection}

Benthic habitat maps defining coral reef spatial extent and coral cover percentage (appendix 3) were used to delineate the location of nearshore coral reefs and their relative coral abundance along the reef-lined shorelines (fig. 4). Cross-shore transects were created every $100 \mathrm{~m}$ alongshore (appendix 4) using the Digital Shoreline Analysis System (DSAS) software version 4.3 in ArcGIS version 10.3 (Thieler and others, 2009).
Transects were cast in both landward and seaward directions using the smoothed baseline cast method with a 500-m smoothing distance, perpendicular to a baseline generated from coastlines digitized from USGS 1:24,000 quadrangle maps and smoothed in ArcGIS using the polynomial approximation with exponential kernal algorithm and a 5,000 m smoothing tolerance (fig. $2 E$ ). Transects varied in absolute length to ensure each intersected the $-30 \mathrm{~m}$ and $+20 \mathrm{~m}$ elevation contours. The bathymetric (appendix 5) and coral coverage (appendix 3) data were extracted along these shore-normal transects at a gridcell cross-shore resolution of $1 \mathrm{~m}$.

The nearshore wave time series (hourly data from 1948 to 2008) were fit to a General Extreme Value (GEV) distribution (Méndez and others, 2006; Menéndez and Woodworth, 2010) to obtain the significant wave heights associated with the 10-, 50-, 100-, and 500-year storm return periods (fig. 2F). The corresponding 10-, 50-, 100-, and

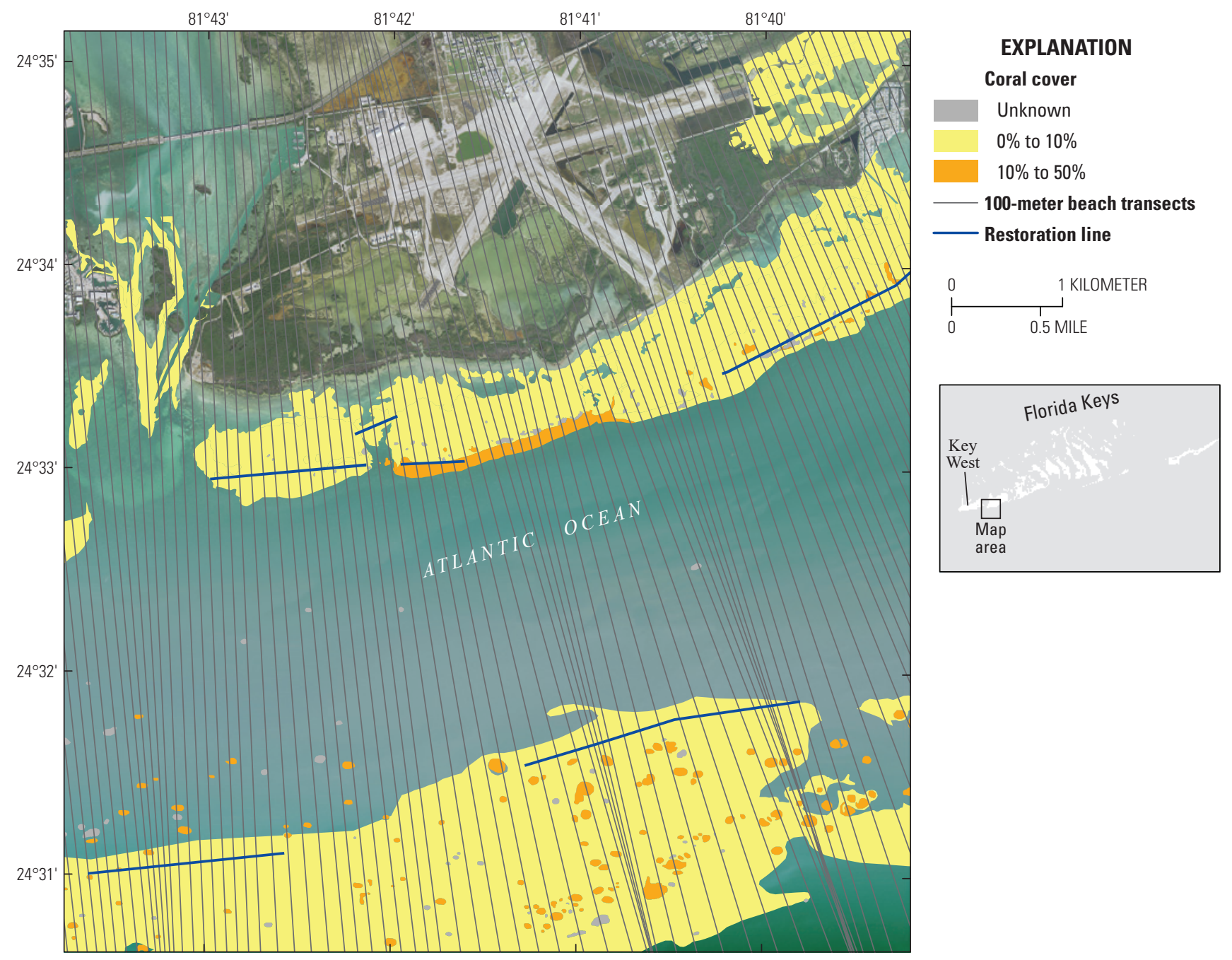

Figure 4. Example map showing the coral extent, coral coverage (Florida Fish and Wildlife Conservation Commission, 2016), and locations of theoretical coral reef restorations offshore Key West, Florida. Colors patches indicate percentage (\%) of coral coverage; the blue lines denote the locations of the theoretical coral restoration locations; black lines show cross-beach transects at 100-meter intervals. Note how some restoration locations are far offshore and (or) in relatively deep water because of the lack of suitable benthic habitat closer to shore and shallower. 
500-year storm return period extreme water levels for a given location were taken from the nearest National Oceanic and Atmospheric Administration (NOAA) tidal station (National Oceanic and Atmospheric Administration, 2017), which include the effects of tropical cyclones.

The return value significant wave heights and associated peak periods were then propagated over the coral reefs with corresponding return-value sea levels along 100-m spaced shore-normal transects (appendix 4) using the numerical model XBeach (Roelvink and others, 2009; Deltares, 2016), as demonstrated in figures $2 G$ and 4 . XBeach solves for waterlevel variations up to the scale of long (infragravity) waves using the depth-averaged, non-linear shallow-water equations. The forcing is provided by a coupled wave action balance in which the spatial and temporal variations of wave energy due to the incident-period wave groups are solved. The radiation stress gradients derived from these variations result in a wave force that is included in the non-linear shallow-water equations and generates long waves and water level setup within the model. Although XBeach was originally derived for mildsloping sandy beaches, with some additional formulations, it has been applied in reef environments (Pomeroy and others, 2012; van Dongeren and others, 2013; Quataert and others, 2015; Storlazzi and others, 2018) and proved to accurately predict the key reef hydrodynamics.

XBeach was run for 3,600 seconds (s) in one-dimensional hydrostatic mode along the cross-shore transects, at a varying resolution between $10 \mathrm{~m}$ seawards and $1 \mathrm{~m}$ landwards (resolution varies depending on depth); the runs generally stabilized after 100-150 s and thus generated good statistics on waves and wave-driven water levels for more than 50 minutes (appendix 6). The application of a one-dimensional model neglects some of the dynamics that occur on natural reefs, such as lateral flow. However, it does represent a conservative estimate for infragravity wave generation and wave runup, as the forcing is shore normal. As stated above, the choice is warranted in this case because the observations show nearnormally offshore waves (such as wave propagation modeled with SWAN).

The additional formulations that incorporate the effect of higher bottom roughness on incident wave decay through the incident wave friction coefficient $\left(f_{w}\right)$ and the current and infragravity wave friction coefficient $\left(c_{f}\right)$, as outlined by van Dongeren and others (2013), were applied. The friction induced by corals was parameterized based on the spatially varying coral coverage data and results from a meta-analysis of wave breaking studies over various reef configurations and friction coefficients for the different coral coverages (for example, van Dongeren and others, 2013; Quataert and others, 2015). Coral coverage classes, as established by the benthic habitat maps, were assigned $f_{w}$ and $c_{f}$ (table 1) over the spatial extent of the reef along the profile as defined from the benthic habitat maps (appendix 3). Profiles of total water levels (setup plus runup) at each grid cell over the profiles were then extracted to define the wave-driven flooding along each of the profiles.
Table 1. Wave and current friction coefficients for different percentages of coral cover as determined from benthic habitat maps following Storlazzi and others (2019).

\begin{tabular}{lcc}
\hline $\begin{array}{c}\text { Coral coverage, } \\
\text { in percent }\end{array}$ & $\begin{array}{c}\text { Wave friction } \\
\text { coefficient }\left(\boldsymbol{f}_{\boldsymbol{w}}\right)\end{array}$ & $\begin{array}{c}\text { Current and infragravity } \\
\text { wave friction coefficient }\left(\boldsymbol{c}_{\boldsymbol{f}}\right)\end{array}$ \\
\hline None (sand) & 0.10 & 0.01 \\
$0-10$ & 0.15 & 0.07 \\
$10-50$ & 0.30 & 0.10 \\
$50-90$ & 0.45 & 0.13 \\
$90-100$ & 0.60 & 0.15 \\
\hline
\end{tabular}

\section{Reef Restoration Scenarios}

We worked with stakeholders, scientists, and decision makers to develop three generalized restoration scenarios that considered: (i) likelihood of delivering flood reduction benefits, (ii) existing coral restoration practices, and (iii) permitting factors such as depth for potential navigational hazards. We developed three coral reef restoration scenarios:

1. Ecological ('E25'). This represents solely planting new corals over a distance of $25 \mathrm{~m}$ in the cross-shore direction (horizontal width of restoration), represented by $+0.25 \mathrm{~m}$ increase in height and 0.45 and 0.13 increases in hydrodynamic roughness for $f_{w}$ and $c_{f}$, respectively, owing to the presence of the corals over the 25 m-wide extent

2. Structural plus ecological ('S25'). This represents the emplacement of a $1 \mathrm{~m}$-high solid structure over a distance of $25 \mathrm{~m}$ in the cross-shore direction and planting new corals on top of the structure, represented by $+1.25 \mathrm{~m}$ increase in height and 0.45 and 0.13 increases in hydrodynamic roughness for $f_{w}$ and $c_{f}$, respectively, owing to the presence of the corals over the 25 m-wide extent.

3. Structural plus ecological ('S05'). This represents the emplacement of a $1 \mathrm{~m}$-high solid structure over a distance of $5 \mathrm{~m}$ in the cross-shore direction and planting new corals on top of the structure, represented by $+1.25 \mathrm{~m}$ increase in height and 0.45 and 0.13 increases in hydrodynamic roughness for $f_{w}$ and $c_{f}$, respectively, owing to the presence of the corals over the $5 \mathrm{~m}$-wide extent.

We developed an algorithm that placed these restoration scenarios along the entire length of reef with the following conditions. The locations of the restoration lines along and across shore were defined by the presence of continuous coral/ hardbottom habitat of greater than $100 \mathrm{~m}$ alongshore length and proximity to the $3-\mathrm{m}$ depth contour. The ArcGIS simplify line tool was used to create a general 3-m depth contour and the result was clipped to the current coral/hardbottom extent from existing benthic habitat maps. A 25-m buffer was applied and then manually edited so the restoration areas would 
only lie completely within the coral/hardbottom footprint. Restoration locations were not established shallower than the 2-m contour or deeper than the 7-m contour for operational considerations and were placed as close to shore as possible on continuous coral/hardbottom habitat. Restoration locations were not established in areas less than $100 \mathrm{~m}$ in length alongshore (spanning two cross-shore profiles), nor if no coral or hardbottom was present along a cross-shore profile.

\section{Evaluating the Role of Potential Coral Reef Restoration in Increasing Coastal Protection}

The wave and sea level conditions were then propagated using the XBeach over the same 100-m spaced shore-normal transects modified to account for three coral reef restoration scenarios (fig. 2G). The increase in coral cover and thus rugosity and frictional effects (for example, Quataert and others, 2015) was parameterized by setting the $f_{w}$ and $c_{f}$ to that of 50-90 percent coral cover ( 0.45 and 0.13 , respectively, per table 1 in van Dongeren and others (2013). The vertical height of the coral or emplacement of new structure was parameterized by increasing the elevation (decreasing the depth) of the shore-normal profile over the spatial extent of the restoration along the profile.

Profiles of total water levels (setup plus runup) at each grid cell over the profiles were then extracted to define the wave-driven flooding along these cross-shore profiles with the influence of the different coral reef restoration scenarios (fig. 5).

\section{Quantifying the Social and Economic Benefits of Potential Coral Reef Restoration}

Wave-driven total water level depths and extents were then interpolated between adjacent shore-normal transects for the four return intervals (fig. $2 H$ ) to develop flood mask layers for the total water levels with and without restoration (fig. 2I). The flood masks were derived by creating an interpolated flood surface raster with values representing absolute water

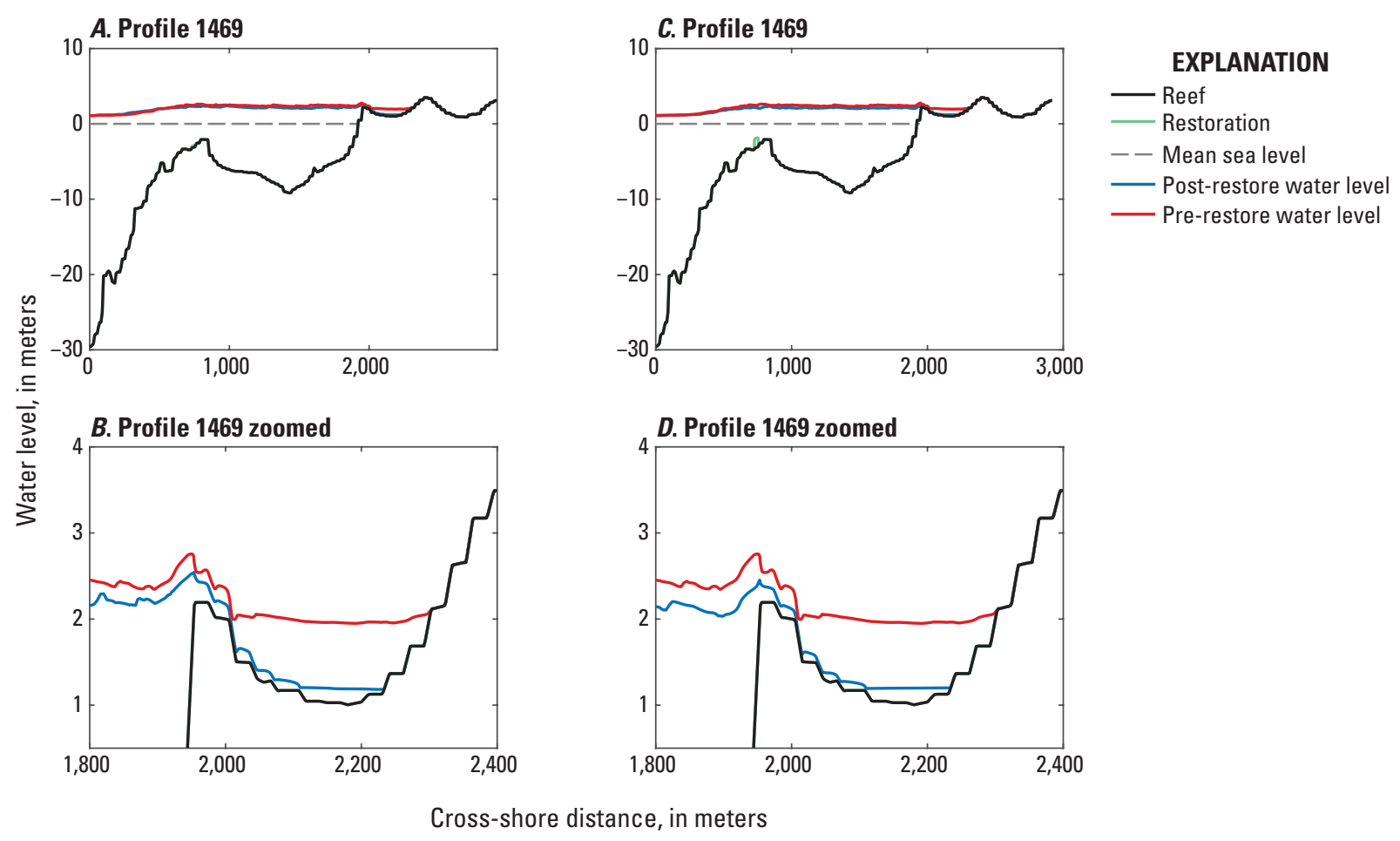

Figure 5. Plots of example Puerto Rico topographic-bathymetric cross-sections and XBeach model wave-driven total water levels, in meters, during the 100-year storm for current reefs and with restored reefs. $A$, Cross-shore profile 1469 off San Juan with solely ecological restoration. B, Zoomed-in view of profile 1469 with solely ecological restoration. $C$, Cross-shore profile 1469 with structural plus ecological restoration. $D$, Zoomed-in view of profile 1469 with structural plus ecological restoration. The black line denotes topography and bathymetry, the red line the total water levels (setup plus runup) with current coral reefs, and the blue line the total water levels with restored coral reefs. Note the high vertical exaggeration. 
level (flood depth + elevation) and then taking the difference between that surface and the elevation. The extent of the water depth raster defined the flood mask (fig. 6). Any pixels with a positive value were retained as flood-water depth (fig. 7). To correct areas of disconnected backshore pooling, any pixel regions that were discontinuous with the coastline were removed. The resultant raster was then converted to a polygon feature class and clipped by a land polygon feature class derived from the DEM (where values were greater than zero). Finally, to account for stochasticity of XBeach model runs, the flood mask output polygons were put through a series of topological rules for the flooded pixels where, for each return period: pre-storm scenario $<$ post-storm scenario, and for each scenario: 10 -year return period $<50$-year return period $<100$-year return period $<500$-year return period.

The flood surface used to derive the flood masks was computed as the product of a natural neighbor interpolation of XBeach model flood points (points in space, with information on flood water depth and elevation along each transect spaced $100 \mathrm{~m}$ ) and a distance-weighted multiplier between 0 and 1 , calculated as an exponential function of distance from the flood extent along each transect. Within $50 \mathrm{~m}$ of the flooded section of each transect, the multiplier is equal to 1 (in application, retaining 100 percent of the interpolated flood value) and exponentially decreases to zero at a distance of $500 \mathrm{~m}$ (no flooding regardless of interpolated flood value). This method allowed for a more realistic flood zone to be created between transects while honoring the known flood extents.

In Puerto Rico, which contains regions that do not have parallel transect incidence angles (high crenulation) and thus consistent cross-shore transect spacing, points were generated between the intersection point of each transect and the coastline at intervals of about $20 \mathrm{~m}$. The mean water level of all flood points for each transect was calculated and a linear interpolation of these values between each transect pair was applied to each successive point along the coast

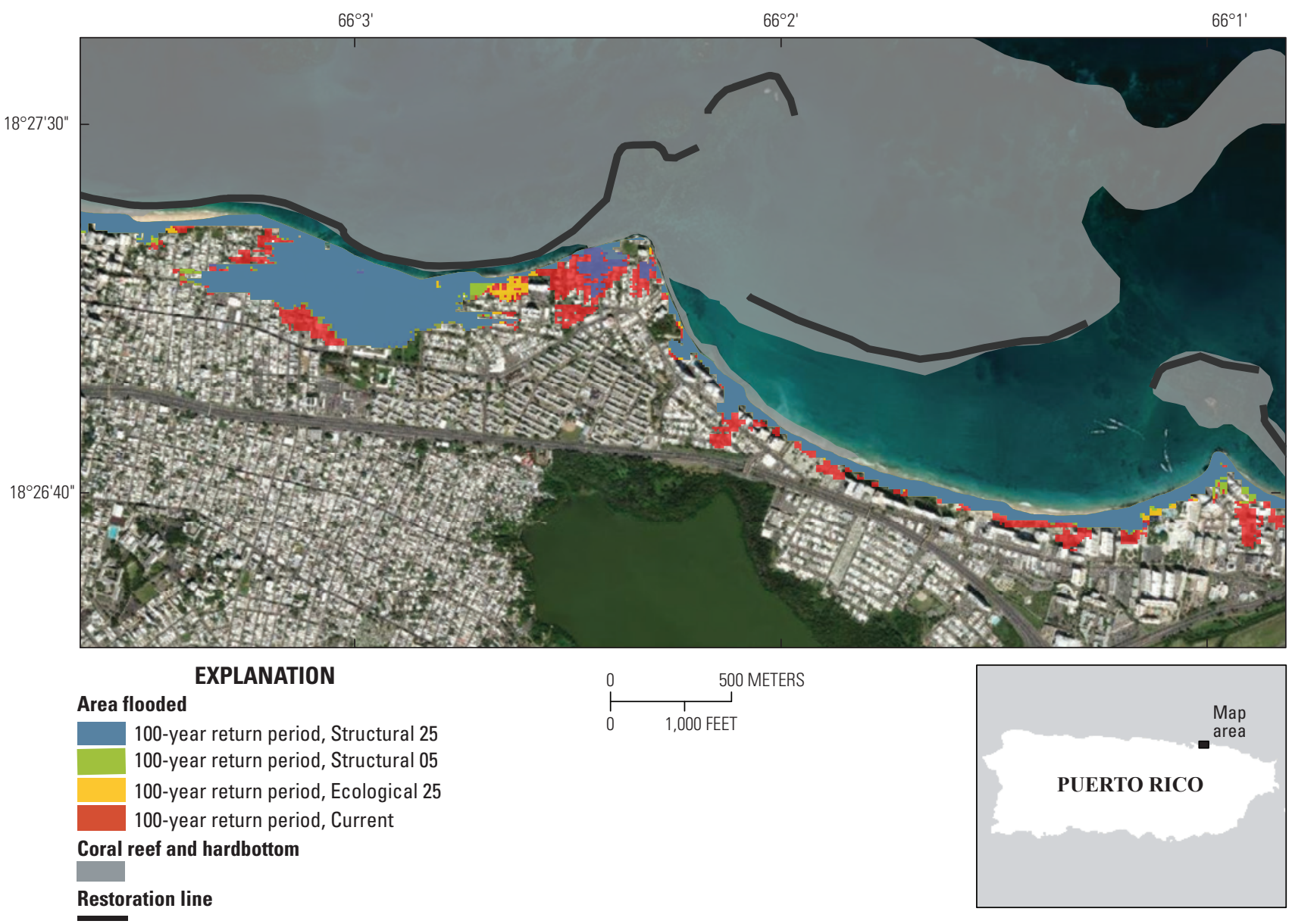

Figure 6. Map showing example 100-year floodplains for both with and without (red) the E25 (ecological over 25-meter [m] width, yellow), S05 (structural and ecological over 5-m width, green), and S25 (structural and ecological over 25-m width, blue) coral reef restoration scenarios on Isla Verde, San Juan, Puerto Rico. The regions protected by coastal flooding because of the coral reef restoration scenarios for the 100-year return-interval storm are therefore in the red, yellow, and green bands. 


\section{A. 10-year return interval}
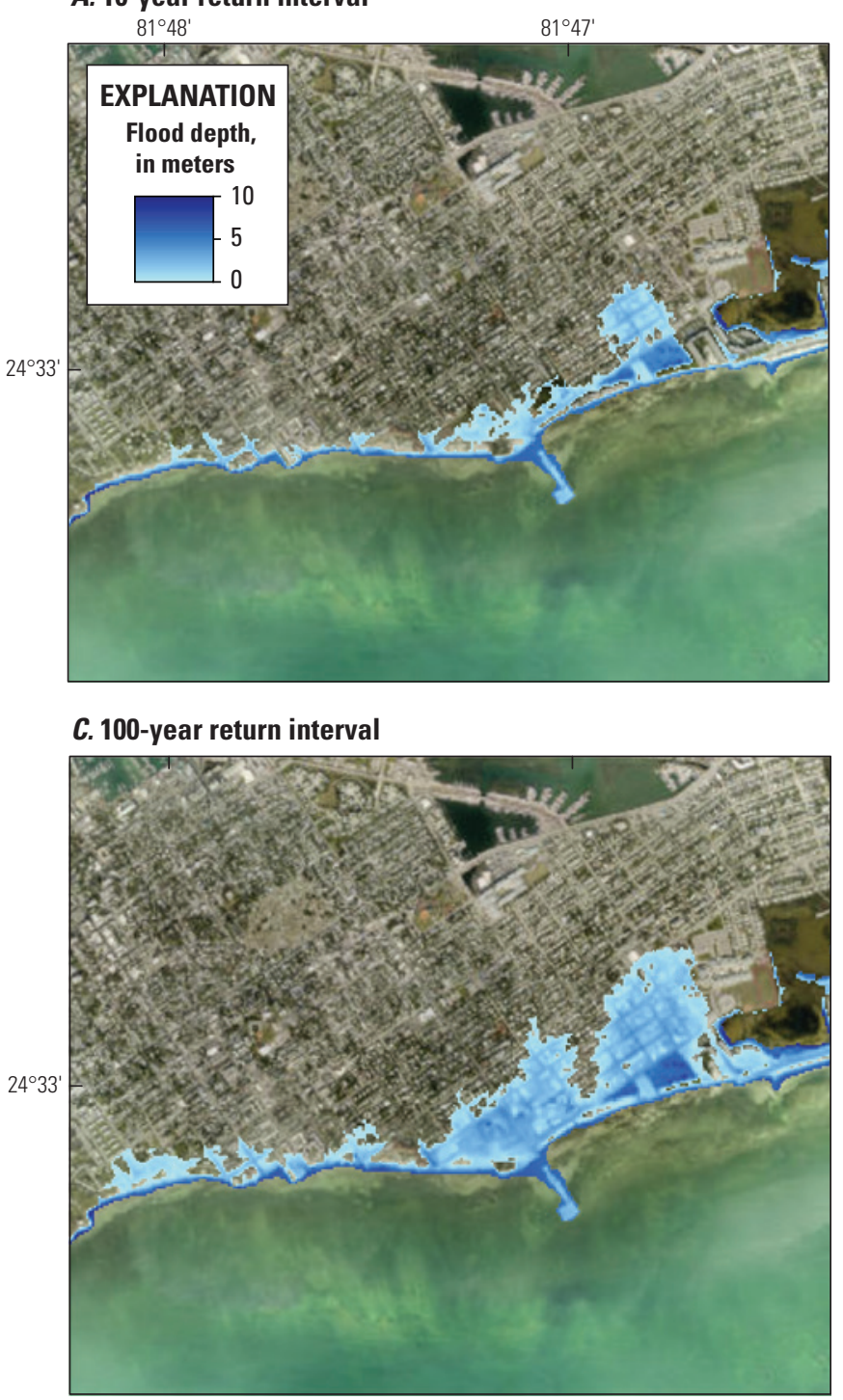

0

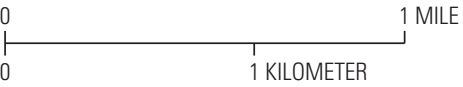

B. 50-year return interval

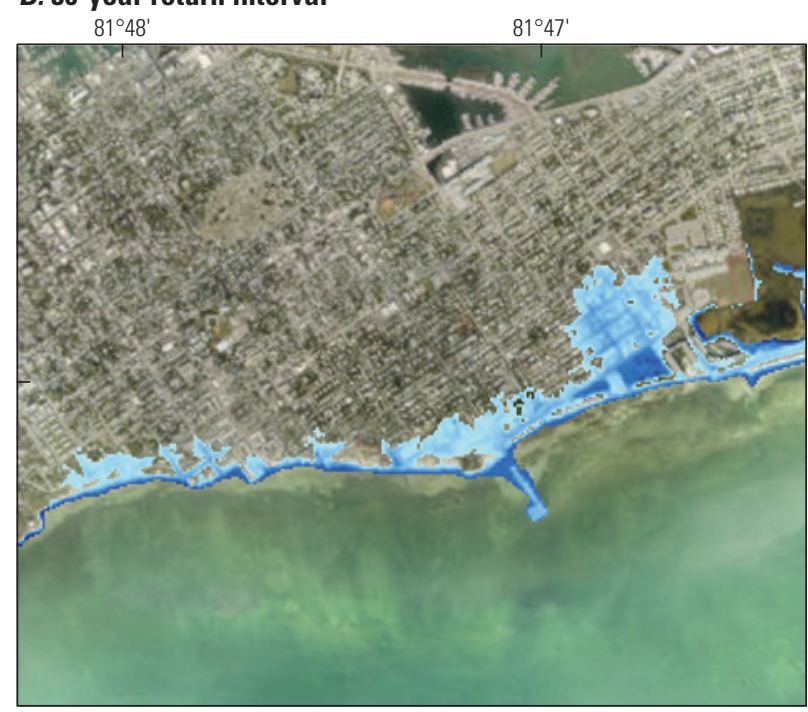

\section{500-year return interval}

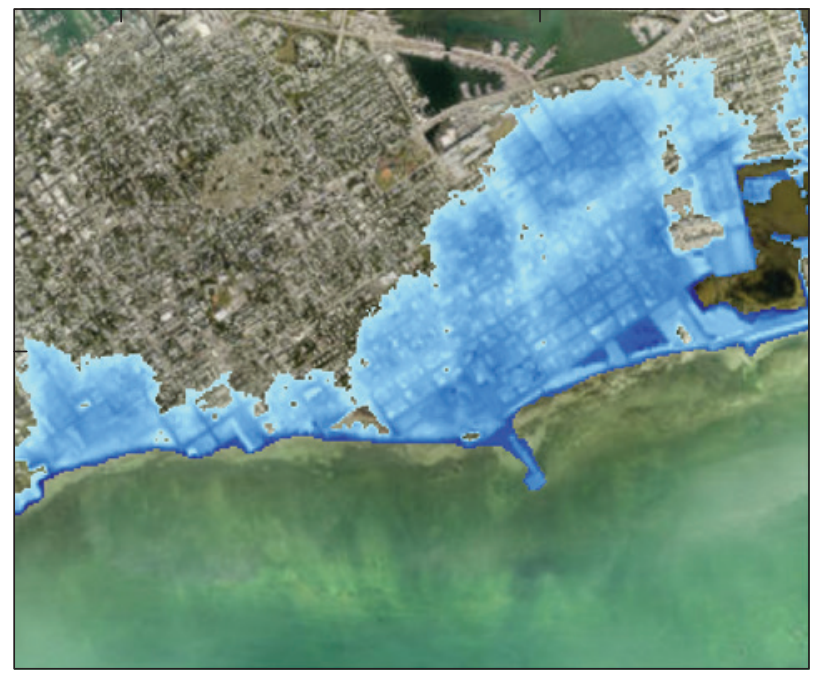

1 MILE

Figure 7. Maps showing example 10-meter $(\mathrm{m})$ resolution flood depths for various storm recurrence intervals on Key West, Florida. A, 10-year storm. B, 50-year storm. C, 100-year storm. D, 500-year storm. Colors indicate flood-water depth, in meters, interpolated from adjacent XBeach model profile model transects spaced every 100 meters along the coast.

between transect intersections. These points were merged with the XBeach model flood points prior to the natural neighbor interpolation in Puerto Rico to augment gaps between the modeled XBeach flood points. For each flood mask, the cells flooded by wave-driven setup and runup for both scenarios were logged and areas computed (fig. $2 J$ ).

The resulting number of people threatened, building damage, and indirect economic impact were then computed using the wave-driven flood depths. The people impacted by wave-driven flooding were determined by cross-referencing the flooded cells with the U.S. Census Bureau's (2016) TIGER database, as shown in figure 8 . The number of people at risk from flooding were calculated from the intersection between the flood depth raster and people per unit area. The built infrastructure impacted by wave-driven flooding was determined by cross-referencing the flooded cells with the Federal Emergency Management Agency's (2016b) flood hazard exposure data in the HAZUS database (Scawthorn 

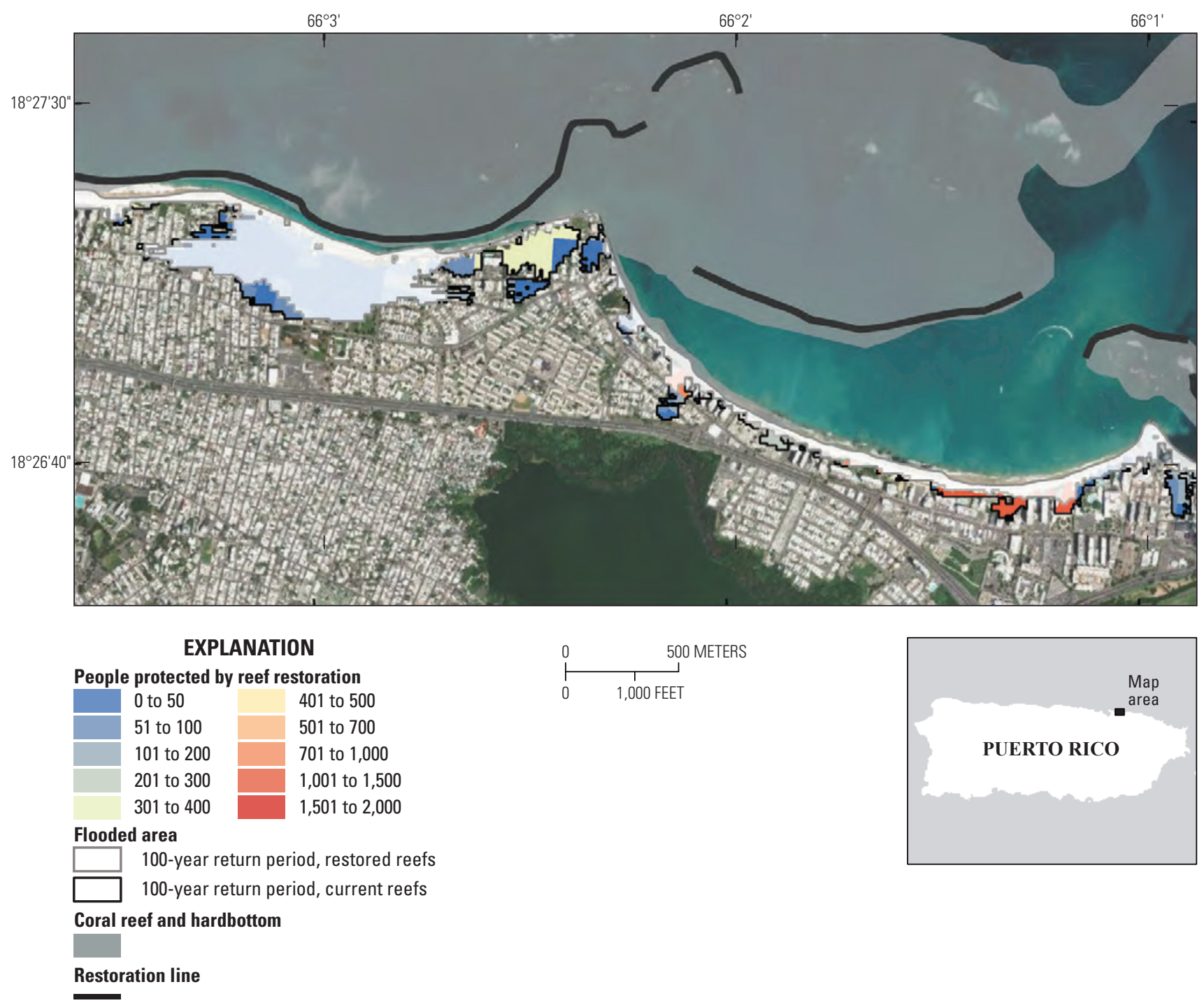

Figure 8. Map showing the distribution of people protected from coastal flooding from the S05 (structural and ecological over 5-meter width) coral reef restoration scenario for the 100-year storm eastern San Juan, Puerto Rico. Colors indicate the population density, based on U.S. Census Bureau's 2010 TIGER data, in the area protected from flooding by the reef restoration.

and others, 2006a, 2006b). The data were projected into each respective Universal Transverse Mercator Coordinate System (coordinate system from the transects belonging to that region).

For each type of HAZUS asset (for example, different types of residential, commercial and industrial buildings), a damage degree raster was created using the damage functions found in HAZUS (fig. $2 K$ ) for the different categories of infrastructure following the methodology of Wood and others (2013), as shown in figure 9. These damage functions relate flood-water depth with the degree of damage (percentage of damage to each type of building). The damage degree raster was built from the flood depth raster and every cell represents the degree (or percent) of damage from flooding, with values ranging from 0.0 (no damage) to 1.0 (complete damage). Once the damage degree rasters were built, the economic value of the damage (in 2010 U.S. dollars) was calculated for each asset: building value per unit area multiplied by degree of damage. Similarly, the number and extent flooded buildings were calculated by intersections between the flood depth raster and buildings (and specific building types) per unit area, as shown in figure 9. Finally, building damage, number of flooded buildings, and people flooded were aggregated to summary points. The summary points were created as regularly $10-\mathrm{m}$ spaced points within the union between all 


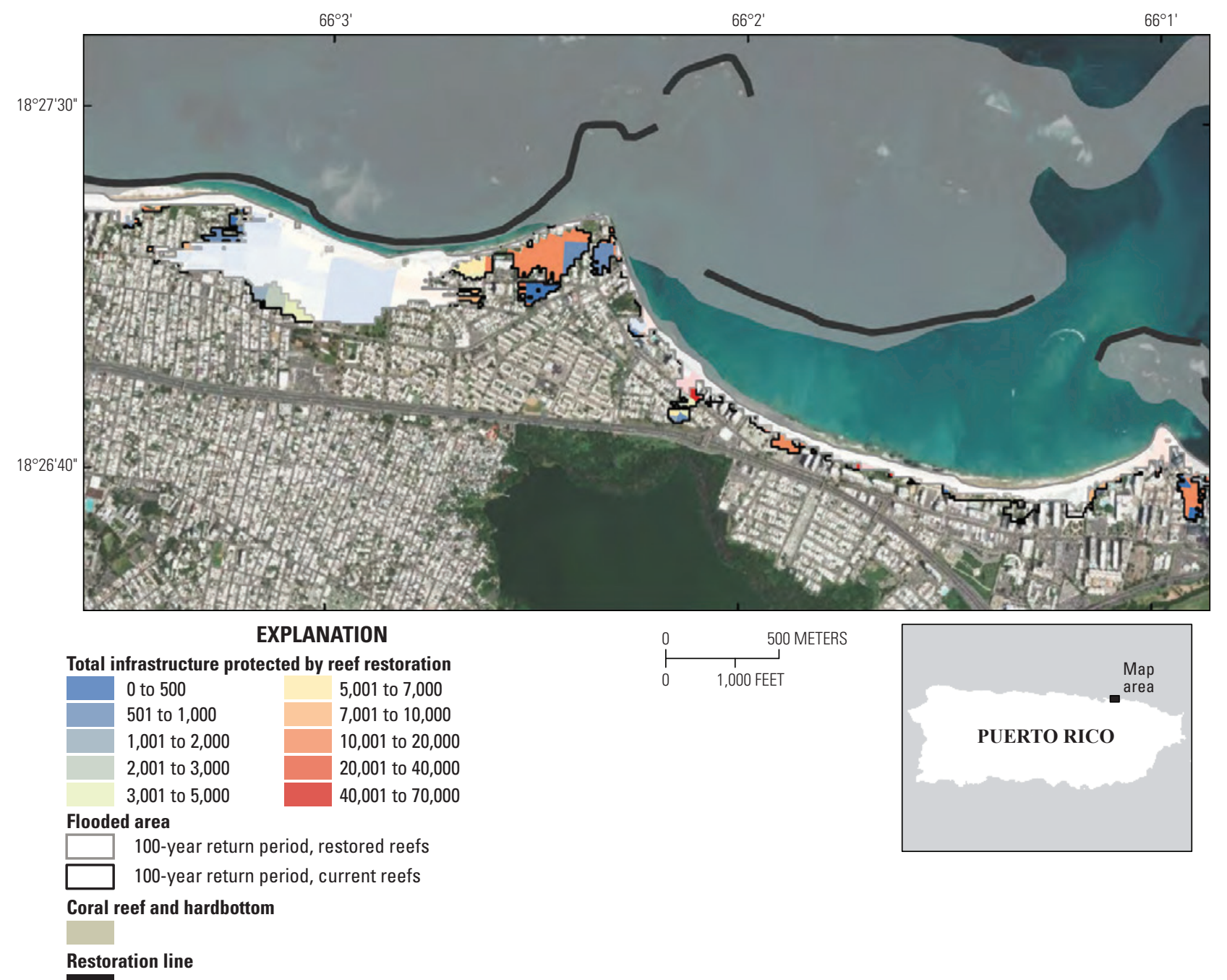

Figure 9. Map showing the value of infrastructure, in thousands of 2010 U.S. dollars, protected from coastal flooding from the $\mathrm{S} 05$ (structural and ecological over 5-meter width) coral reef restoration scenario for the 100 -year storm on eastern San Juan, Puerto Rico. Colors indicate the total value of infrastructure, based on the Federal Emergency Management Agency's HAZUS data, in the area protected from flooding by the reef restoration.

flood extents. Each point was assigned a transect ID and coral cover attribute based on nearest transect.

The value of the coral reef restoration in terms of decreased coastal hazard risk was then determined as the difference in people and infrastructure impacted by wavedriven flooding in the simulations for current coral reef conditions compared to those with the three coral reef restoration scenarios (fig. $2 L$ ). The calculated damages by infrastructure type were aggregated and summarized into tables (see results section) for each return period. The infrastructure was categorized into the types of the general building stock that includes residential, commercial, industrial, agricultural, religious, government, and education buildings.
Damage was estimated in percent and weighted by the area of flooding at a given depth for a given HAZUS census block. The entire composition of the general building stock within a given census block was assumed to be evenly distributed throughout the block.

A storm return period, $t_{i}$, also known as a recurrence interval, is the inverse of the probability of occurring and an estimate of the likelihood of such a storm event. For example, a 100-year return period of a flood represents a probability of the flood occurring in a given year of 1/100. The damages associated with the probability of occurrence characterize risk for the four reef scenarios: current (no restoration) conditions and with the three coral reef restoration scenarios. The 
expected annual damage (EAD) is the frequency-weighted sum of damages for the full range of possible damaging flood events and is a measure of what might be expected to occur in a given year. The EAD was calculated from each damage curve (pre-restoration and post-restoration, figure 10) as:

$$
E A D=\frac{1}{2} \sum_{i=1}^{n}\left(\frac{1}{t_{i}}-\frac{1}{t_{i+1}}\right)\left(D_{i}+D_{i+1}\right)
$$

where:

$E A D$ is the frequency-weighted sum of damages for the full range of possible damaging flood events;

$i \quad$ is the specific storm return period number;

$n \quad$ is the total number of different storm return periods (in this case, $n=4$ );

$t_{i} \quad$ is the storm return period, also known as the recurrence interval; and

$D_{i} \quad$ represents the loss in the damage curve (fig. $2 L$ ) for the probability of $1 / T_{i}$, per Olsen and others (2015).

The benefits were calculated as the difference in damages between the scenarios: current reefs and restored reefs (fig. 10). The expected annual loss (EAL), a measure of the annual loss of protection provided coral reefs (or increased exposure) owing to the projected degradation, is calculated as:

$$
E A L=E A D_{\text {post-storms }}-E A D_{\text {pre-storms }}
$$

The total economic impact of wave-driven coastal flooding, however, is not only the direct physical damage to structures themselves, but also to the disruption of peoples' and businesses' incomes and thus the contribution to the gross domestic product (GDP) of that housing and commercial/ industrial infrastructure, respectively (Federal Emergency Management Agency, 2018). This indirect damage is calculated by multiplying the 2010 average contribution to the GDP per person (table 2; U.S. Bureau of Economic Analysis, 2018) to the number of people living in the regions no longer exposed to flooding because of the coral reef restoration. One can compute the economic activity protected by reefs for people that would no longer be displaced owing to the loss of housing from decreased coastal flooding. Similarly, by multiplying the 2010 average of 15.1 employees per business (U.S. Census Bureau, 2018) to the 2010 average contribution to the GDP per person (table 2; U.S. Bureau of Economic Analysis, 2018) to the number of commercial and industrial buildings in the regions no longer exposed to flooding because of the coral reef restoration, one can compute the economic activity no longer lost for businesses impacted owing to the loss of infrastructure from decreased coastal flooding. Because there are no data linking the people living in an area to where those people work, we assume here that the economic activity lost for people displaced by the loss of housing from coastal flooding is independent from the economic activity lost for businesses impacted by the loss of infrastructure from coastal flooding.

Table 2. Gross domestic product (GDP) per person by island or region.

[Data from Bureau of Economic Analysis (2018)]

\begin{tabular}{lc}
\hline \multicolumn{1}{c}{ Location } & GDP (in 2010 U.S. dollars) \\
\hline Florida & 38,604 \\
Puerto Rico & 26,436 \\
\hline
\end{tabular}
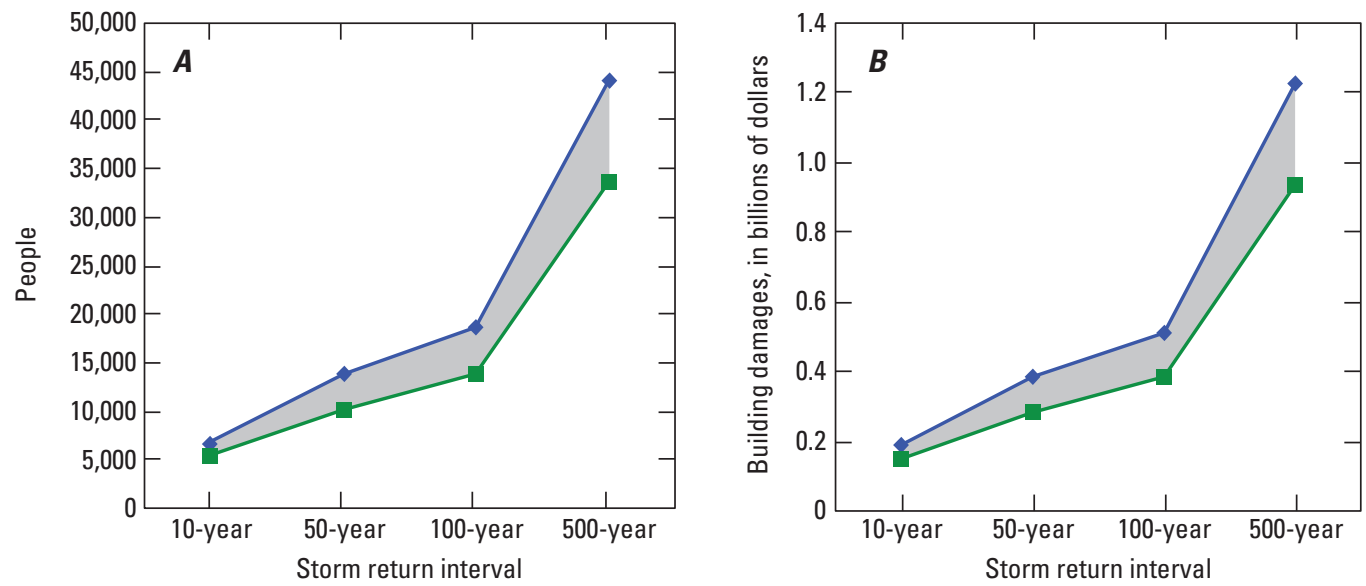

\section{EXPLANATION}

$\sim$ Current

$\rightarrow-$ Restoration

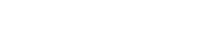

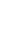




\section{Uncertainties, Limitations, and Assumptions}

Numerical flood modeling errors were estimated to be $\pm 0.5 \mathrm{~m}$. This value is greater than the root-mean-square and absolute errors computed between model results and measurements (van Dongeren and others, 2013; Quataert and others, 2015) but was used in an effort to mitigate the fact that the number of storms tested are few and the geographic scope is large compared to regions where validation measurements are available. The vertical resolution of the HAZUS depthdamage curves is $\pm 0.3 \mathrm{~m}$. Uncertainties associated with the baseline DEM varied based on input data; see references listed in appendix 5. Other limitations and assumptions pertaining to flood extents and the resulting computed social and economic consequences include:

- The extreme value analysis for selecting storm return periods was stationary and did not include nonstationary effects, such as interannual patterns like El Niño, in the selection of values. The fit of each time series had to be limited to a number of thresholds and could not be adapted iteratively. These thresholds were also different for each region, depending on the local characteristics of extremes in each time series (with a limit of at least 30 extreme values to fit the extreme value distribution).

- Because the coral coverage data are defined in 5 classes, the associated hydrodynamic roughness data are also classified in 5 classes. This results in a stepwise change in hydrodynamic roughness that can occur over a relatively small distance defining two different coral coverage class polygons that could result from a small change ( 2 percent; for example, between 9 percent to 11 percent cover) in coral cover.

- Restoration scenarios were assumed to have consistent extents of coral composed of species that contribute to wave attenuation (for example, Acropora palmata). Coral restoration was considered to be successful in terms of survival and growth of outplants. Specieslevel habitat limitations were not included in this study.

- The model scheme used to define the extreme flood levels were a combination of the wave and surge conditions for certain storm probabilities and did not consider dependencies between both variables or the joint distribution of wave heights, wave periods, and surge levels. However, it is likely that large surges and waves occur simultaneously for large return periods.

- We did not consider tide levels, beyond those registered in the extreme values measured in the tidal gauges that were used to define the extreme sea level for each region.

- The modeling structure of one-dimensional cross-shore transects assumes shore-normal wave and flooding processes.
- The approach for assessing flood damages and the resulting benefits associated with each probability assumes that the probability of the extreme flooding conditions on the fore reef defines the probability of the flood zones and the resulting flood damages (thus, the 1-in-100-year total water level represents the 1-in-100-year damage).

- The most statistically accurate assessment of flood damages would require defining the statistical distribution of damages, instead of flood levels - for example, calculating the extreme economic damages. However, this requires the reconstruction of the runup time series and the calculation of spatial losses associated with each event, which is outside the scope of this work.

- Alternative ways to calculate these statistics of economic damages would imply taking larger simplifications and uncertainties in the modeling of flooding, which would likely affect the accuracy of the results.

- Flood depths and extents between cross-shore transects modeled are alongshore interpolations and are not exact representations of model output, as they did not consider topographic features between the transects.

- U.S. Census Bureau's (2016) TIGER/Line data and FEMA's (2016b) flood hazard exposure data in the HAZUS database are based on the 2010 census, and, thus, may not reflect current-day populations, demographics, building values, and distributions.

- The composition of the general building stock within a given census block was assumed to be evenly distributed throughout the block.

- The 2010 average of 15.1 employees per business was uniformly applied to the number of commercial and industrial buildings to compute the economic activity protected for businesses not impacted by the loss of infrastructure from coastal flooding.

- The economic activity protected for people not displaced by the loss of housing from coastal flooding is independent from the economic activity protected for businesses not impacted by the loss of infrastructure from coastal flooding.

\section{Results}

\section{Flooding Extents}

This section summarizes the gain of coastal flood protection (decreased exposure) because of the E25 (ecological over 25-m width), S25 (structural and ecological over $25-\mathrm{m}$ width), and S05 (structural and ecological over 5-m width) coral reef restoration scenarios for each region considered 
in the analysis for the 4 storm return periods. The gains are expressed in terms of land surface and number and value of buildings or assets no longer exposed to coastal flooding owing to the three coral reef restoration scenarios. The benefits are calculated as the differences between current (no restoration) and each of the three restoration scenarios.
The expected annual benefit (EAB), or annual gain of area protected from coastal flooding because of the E25, S25, and S05 coral reef restoration scenarios are $1.80 \mathrm{~km}^{2}\left(0.69 \mathrm{mi}^{2}\right)$, $1.86 \mathrm{~km}^{2}\left(0.72 \mathrm{mi}^{2}\right)$, and $1.79 \mathrm{~km}^{2}\left(0.69 \mathrm{mi}^{2}\right)$, respectively, in Florida and $3.81 \mathrm{~km}^{2}\left(1.47 \mathrm{mi}^{2}\right), 4.42 \mathrm{~km}^{2}\left(1.71 \mathrm{mi}^{2}\right)$, and 4.10 $\mathrm{km}^{2}\left(1.58 \mathrm{mi}^{2}\right)$, respectively, in Puerto Rico (tables 3-5).

Table 3. Spatial extent, in square kilometers, of area protected from coastal flooding because of the E25 (ecological over 25-meter width) coral reef restoration scenario for different return-interval storms by region.

\begin{tabular}{|c|c|c|c|c|c|}
\hline \multirow{2}{*}{ Location } & \multirow{2}{*}{ Sublocation } & \multicolumn{4}{|c|}{ Storm Return Interval } \\
\hline & & 10-year & 50-year & 100-year & 500-year \\
\hline Florida & Martin & 0.26 & 0.88 & 0.37 & 0.44 \\
\hline Florida & Broward & 0.48 & 0.71 & 0.84 & 1.63 \\
\hline Florida & Miami-Dade & 0.80 & 0.98 & 1.17 & 3.05 \\
\hline Florida & Middle Keys & 0.03 & 0.01 & 0.02 & 0.00 \\
\hline Florida & Lower Keys & 0.28 & 0.24 & 0.55 & 0.39 \\
\hline Puerto Rico & San Juan & 0.54 & 0.60 & 0.63 & 1.85 \\
\hline Puerto Rico & Vega Baja & 0.50 & 0.43 & 1.99 & 1.83 \\
\hline Puerto Rico & Arecibo & 1.33 & 1.33 & 1.45 & 1.42 \\
\hline Puerto Rico & Guayama & 0.35 & 0.47 & 0.78 & 0.68 \\
\hline Puerto Rico & Humacao & 0.15 & 0.23 & 0.19 & 0.45 \\
\hline Puerto Rico & Ceiba & 1.06 & 0.71 & 0.97 & 0.86 \\
\hline Puerto Rico & Culebra & 0.16 & 0.15 & 0.15 & 0.16 \\
\hline Puerto Rico & Vieques & 0.13 & 0.24 & 0.29 & 0.33 \\
\hline
\end{tabular}

Table 4. Spatial extent, in square kilometers, of area protected from coastal flooding because of the S25 (structural and ecological over 25-meter width) coral reef restoration scenario for different return-interval storms by region.

\begin{tabular}{|c|c|c|c|c|c|}
\hline \multirow{2}{*}{ Location } & \multirow{2}{*}{ Sublocation } & \multicolumn{4}{|c|}{ Storm Return Interval } \\
\hline & & 10-year & 50-year & 100-year & 500-year \\
\hline Florida & Martin & 0.24 & 0.89 & 0.42 & 0.45 \\
\hline Florida & Broward & 0.45 & 0.67 & 0.87 & 1.63 \\
\hline Florida & Miami-Dade & 0.91 & 0.87 & 1.16 & 3.42 \\
\hline Florida & Middle Keys & 0.03 & 0.02 & 0.01 & 0.00 \\
\hline Florida & Lower Keys & 0.31 & 0.23 & 0.50 & 0.38 \\
\hline Puerto Rico & San Juan & 0.56 & 0.83 & 0.65 & 1.95 \\
\hline Puerto Rico & Vega Baja & 0.96 & 1.37 & 2.01 & 1.97 \\
\hline Puerto Rico & Arecibo & 1.56 & 1.43 & 1.52 & 1.35 \\
\hline
\end{tabular}


Table 4. Continued

\begin{tabular}{llcccc}
\hline \multirow{2}{*}{ Location } & \multicolumn{1}{c}{ Sublocation } & \multicolumn{3}{c}{ Storm Return Interval } \\
\cline { 3 - 5 } & & 10-year & 50-year & 100-year & 500-year \\
\hline Puerto Rico & Mayaguez & 0.82 & 1.82 & 1.03 & 0.96 \\
Puerto Rico & Ponce & 0.67 & 0.81 & 0.98 & 0.60 \\
Puerto Rico & Guayama & 0.35 & 0.48 & 0.34 & 0.69 \\
Puerto Rico & Humacao & 0.15 & 0.43 & 1.17 & 0.53 \\
Puerto Rico & Ceiba & 1.16 & 0.15 & 0.15 & 0.16 \\
Puerto Rico & Culebra & 0.18 & 0.27 & 0.32 \\
Puerto Rico & Vieques & 0.16 & & 0.31 \\
\hline
\end{tabular}

Table 5. Spatial extent, in square kilometers, of area protected from coastal flooding because of the S05 (structural and ecological over 5 -meter width) coral reef restoration scenario for different return-interval storms by region.

\begin{tabular}{llcccc}
\hline \multirow{2}{*}{ Location } & \multicolumn{1}{c}{ Sublocation } & \multicolumn{4}{c}{ Storm Return Interval } \\
\cline { 3 - 5 } & Martin & $\mathbf{1 0}$-year & $\mathbf{5 0}$-year & $\mathbf{1 0 0}$-year & $\mathbf{5 0 0}$-year \\
\hline Florida & Palm Beach & 0.24 & 0.84 & 0.40 & 0.46 \\
Florida & Broward & 0.92 & 2.24 & 2.74 & 2.50 \\
Florida & Miami-Dade & 0.79 & 0.69 & 0.86 & 1.68 \\
Florida & Upper Keys & 0.20 & 0.90 & 0.92 & 3.32 \\
Florida & Middle Keys & 0.03 & 0.77 & 0.52 & 0.44 \\
Florida & Lower Keys & 0.29 & 0.02 & 0.02 & 0.00 \\
Florida & San Juan & 0.56 & 0.25 & 0.53 & 0.39 \\
Puerto Rico & Vega Baja & 0.95 & 0.58 & 0.67 & 1.76 \\
Puerto Rico & Arecibo & 1.34 & 1.32 & 2.10 & 2.04 \\
Puerto Rico & Aquadilla & 1.17 & 1.30 & 1.28 & 2.33 \\
Puerto Rico & Mayaguez & 0.85 & 1.89 & 2.05 & 0.81 \\
Puerto Rico & Ponce & 0.44 & 0.77 & 1.04 & 0.66 \\
Puerto Rico & Guayama & 0.35 & 0.47 & 0.94 & 0.68 \\
Puerto Rico & Humacao & 0.13 & 0.25 & 0.78 & 0.45 \\
Puerto Rico & Ceiba & 1.10 & 0.70 & 0.22 & 0.76 \\
Puerto Rico & Culebra & 0.16 & 0.14 & 1.13 & 0.19 \\
Puerto Rico & Vieques & 0.14 & 0.26 & 0.14 & 0.30 \\
Puerto Rico & & & 3.31 & \\
\hline
\end{tabular}

\section{Social Benefits}

The Expected Annual Benefit, in terms of the annual number of people who gained protection from coastal flooding owing to coral reef restoration because of the E25 (ecological over 25-m width), S25 (structural and ecological over 25-m width), and S05 (structural and ecological over 5-m width) coral reef restoration scenarios are 2,247, 2,213, and 2,249 people, respectively, in Florida and 954, 1,047, and 924 people, respectively, in Puerto Rico (tables 6-8). 
Table 6. Total number of people protected from coastal flooding because of the E25 (ecological over 25-meter width) coral reef restoration scenario for different return-interval storms by region.

\begin{tabular}{llrrrr}
\hline \multirow{2}{*}{ Location } & \multicolumn{1}{c}{ Sublocation } & \multicolumn{3}{c}{ Storm Return Interval } \\
\cline { 3 - 6 } & & $\mathbf{1 0}$-year & $\mathbf{5 0}$-year & $\mathbf{1 0 0}$-year & 500-year \\
\hline Florida & Martin & 34 & 98 & 98 & 33 \\
Florida & Palm Beach & 1,549 & 2,576 & 2,808 & 2,456 \\
Florida & Broward & 800 & 885 & 3,383 & 5,257 \\
Florida & Miami-Dade & 1,216 & 1,284 & 3,650 & 9,030 \\
Florida & Upper Keys & 65 & 54 & 35 & 27 \\
Florida & Middle Keys & 7 & 3 & 3 & 0 \\
Florida & Lower Keys & 109 & 255 & 436 & 527 \\
Puerto Rico & San Juan & 418 & 1,003 & 1,456 & 4,033 \\
Puerto Rico & Vega Baja & 153 & 327 & 337 & 818 \\
Puerto Rico & Arecibo & 275 & 688 & 853 & 895 \\
Puerto Rico & Aquadilla & 286 & 1,006 & 1,110 & 1,731 \\
Puerto Rico & Mayaguez & 109 & 505 & 380 & 1,034 \\
Puerto Rico & Ponce & 63 & 117 & 263 & 174 \\
Puerto Rico & Guayama & 53 & 99 & 145 & 185 \\
Puerto Rico & Humacao & 22 & 25 & 21 & 68 \\
Puerto Rico & Ceiba & 46 & 18 & 100 & 590 \\
Puerto Rico & Culebra & 0 & 10 & 19 & 9 \\
Puerto Rico & Vieques & 2 & & 7 & 19 \\
\hline
\end{tabular}

Table 7. Total number of people protected from coastal flooding because of the S25 (structural and ecological over 25-meter width) coral reef restoration scenario for different return-interval storms by region.

\begin{tabular}{llrrrr}
\hline \multirow{2}{*}{ Location } & \multicolumn{1}{c}{ Sublocation } & \multicolumn{4}{c}{ Storm Return Interval } \\
\cline { 3 - 5 } & Martin & $\mathbf{1 0}$-year & $\mathbf{5 0}$-year & $\mathbf{1 0 0}$-year & 500-year \\
\hline Florida & 27 & 98 & 106 & 37 \\
Florida & Palm Beach & 1,475 & 2,523 & 2,839 & 2,416 \\
Florida & Broward & 749 & 857 & 3,415 & 5,100 \\
Florida & Miami-Dade & 1,248 & 1,253 & 3,394 & 10,210 \\
Florida & Upper Keys & 65 & 60 & 44 & 26 \\
Florida & Middle Keys & 9 & 6 & 3 & 0 \\
Florida & Lower Keys & 149 & 201 & 357 & 543 \\
Puerto Rico & San Juan & 424 & 1,158 & 1,538 & 4,656 \\
Puerto Rico & Vega Baja & 141 & 307 & 374 & 830 \\
Puerto Rico & Arecibo & 371 & 747 & 936 & 907 \\
Puerto Rico & Aquadilla & 318 & 1,016 & 661 & 1,837 \\
Puerto Rico & Mayaguez & 119 & 1957 & 273 & 121 \\
Puerto Rico & Ponce & 72 & 115 & 175 & 177 \\
Puerto Rico & Guayama & 54 & 25 & 21 & 75 \\
Puerto Rico & Humacao & 23 & 87 & 125 & 449 \\
Puerto Rico & Ceiba & 44 & 18 & 19 & 10 \\
Puerto Rico & Culebra & 0 & 10 & 9 & 20 \\
Puerto Rico & Vieques & 4 & & \\
\hline
\end{tabular}


Table 8. Total number of people protected from coastal flooding because of the S05 (structural and ecological over 5-meter width) coral reef restoration scenario for different return-interval storms by region.

\begin{tabular}{|c|c|c|c|c|c|}
\hline \multirow{2}{*}{ Location } & \multirow{2}{*}{ Sublocation } & \multicolumn{4}{|c|}{ Storm Return Interval } \\
\hline & & 10-year & 50-year & 100 -year & 500-year \\
\hline Florida & Martin & 24 & 74 & 105 & 38 \\
\hline Florida & Broward & 868 & 1,052 & 3,309 & 5,468 \\
\hline Florida & Miami-Dade & 1,191 & 1,461 & 2,888 & 10,420 \\
\hline Florida & Middle Keys & 9 & 7 & 2 & 0 \\
\hline Florida & Lower Keys & 107 & 230 & 410 & 576 \\
\hline Puerto Rico & San Juan & 349 & 924 & 1,542 & 4,093 \\
\hline Puerto Rico & Vega Baja & 139 & 300 & 361 & 808 \\
\hline Puerto Rico & Arecibo & 271 & 635 & 691 & 944 \\
\hline Puerto Rico & Guayama & 56 & 107 & 127 & 179 \\
\hline Puerto Rico & Humacao & 20 & 27 & 22 & 64 \\
\hline Puerto Rico & Ceiba & 47 & 93 & 84 & 514 \\
\hline Puerto Rico & Culebra & 0 & 18 & 18 & 15 \\
\hline Puerto Rico & Vieques & 2 & 9 & 8 & 19 \\
\hline
\end{tabular}

\section{Economic Benefits}

The expected annual benefit, in terms of the annual number of buildings that gain protection from coastal flooding because of the E25 (ecological over 25-m width), S25 (structural and ecological over 25-m width), and S05 (structural and ecological over 5-m width) coral reef restoration scenarios, are 362, 360, and 369 buildings, respectively, in Florida and 529, 587, and 526 buildings, respectively, in Puerto Rico (tables 9-11). The EAB, in terms of the annual value of buildings that gain protection because of the E25, S25, and S05 coral reef restoration scenarios, are $\$ 110,238,262, \$ 109,219,890$, and $\$ 115,084,807$, respectively, in Florida and $\$ 13,986,275, \$ 15,055,348$, and $\$ 13,547,892$, respectively, in Puerto Rico (tables 12-14). The EAB, in terms of the annual value of economic activity that gains protection because of the E25, S25, and S05 coral reef restoration scenarios, are $\$ 121,065,078, \$ 119,050,609$, and $\$ 123,756,391$, respectively, in Florida and $\$ 27,664,676, \$ 30,157,829$, and $\$ 26,474,529$, respectively, in Puerto Rico (tables 15-17). The total EAB, in terms of the annual value of all gained coastal storm flooding protection (sum of tables 12-17) because of the E25, S25, and S05 coral reef restoration scenarios are $\$ 231,303,340, \$ 228,270,499$, and $\$ 238,841,198$, respectively, in Florida and \$41,650,951, \$45,213,177, and \$40,022,421, respectively, in Puerto Rico (tables 18-20). 
Table 9. Total number of buildings (all infrastructure types) protected from coastal flooding because of the E25 (ecological over 25-meter width) coral reef restoration scenario for different return-interval storms by region.

\begin{tabular}{llcccr}
\hline \multirow{2}{*}{ Location } & \multicolumn{1}{c}{ Sublocation } & \multicolumn{4}{c}{ Storm Return Interval } \\
\cline { 3 - 5 } & Martin & $\mathbf{1 0}$-year & $\mathbf{5 0}$-year & $\mathbf{1 0 0}$-year & 500-year \\
\hline Florida & Palm Beach & 13 & 52 & 42 & 16 \\
Florida & Broward & 123 & 890 & 792 & 929 \\
Florida & Miami-Dade & 115 & 180 & 382 & 872 \\
Florida & Upper Keys & 39 & 34 & 476 & 1,931 \\
Florida & Middle Keys & 6 & 2 & 24 & 30 \\
Florida & Lower Keys & 54 & 114 & 125 & 169 \\
Florida & San Juan & 173 & 251 & 334 & 1,157 \\
Puerto Rico & Vega Baja & 113 & 256 & 261 & 508 \\
Puerto Rico & Arecibo & 109 & 282 & 345 & 392 \\
Puerto Rico & Aquadilla & 255 & 588 & 590 & 783 \\
Puerto Rico & Mayaguez & 79 & 258 & 172 & 252 \\
Puerto Rico & Ponce & 30 & 57 & 120 & 84 \\
Puerto Rico & Guayama & 40 & 72 & 98 & 121 \\
Puerto Rico & Humacao & 11 & 14 & 11 & 35 \\
Puerto Rico & Ceiba & 29 & 65 & 61 & 242 \\
Puerto Rico & Culebra & 1 & 13 & 14 & 6 \\
Puerto Rico & Vieques & 2 & 9 & 5 & 12 \\
Puerto Rico & & & & \\
\hline
\end{tabular}

Table 10. Total number of buildings (all infrastructure types) protected from coastal flooding because of the S25 (structural and ecological over 25-meter width) coral reef restoration scenario for different return-interval storms by region.

\begin{tabular}{|c|c|c|c|c|c|}
\hline \multirow{2}{*}{ Location } & \multirow{2}{*}{ Sublocation } & \multicolumn{4}{|c|}{ Storm Return Interval } \\
\hline & & 10-year & 50-year & 100-year & 500-year \\
\hline Florida & Martin & 12 & 52 & 46 & 18 \\
\hline Florida & Palm Beach & 183 & 892 & 773 & 929 \\
\hline Florida & Broward & 123 & 173 & 396 & 859 \\
\hline Florida & Miami-Dade & 114 & 127 & 454 & 2,170 \\
\hline Florida & Upper Keys & 44 & 42 & 31 & 22 \\
\hline Florida & Middle Keys & 6 & 5 & 2 & 0 \\
\hline Florida & Lower Keys & 59 & 93 & 114 & 177 \\
\hline Puerto Rico & San Juan & 172 & 268 & 349 & 1,339 \\
\hline Puerto Rico & Vega Baja & 113 & 235 & 278 & 544 \\
\hline Puerto Rico & Arecibo & 160 & 306 & 373 & 401 \\
\hline Puerto Rico & Aquadilla & 284 & 587 & 626 & 833 \\
\hline Puerto Rico & Mayaguez & 91 & 287 & 311 & 432 \\
\hline Puerto Rico & Ponce & 34 & 76 & 126 & 66 \\
\hline Puerto Rico & Guayama & 41 & 81 & 115 & 118 \\
\hline Puerto Rico & Humacao & 11 & 14 & 11 & 38 \\
\hline Puerto Rico & Ceiba & 36 & 50 & 73 & 178 \\
\hline Puerto Rico & Culebra & 1 & 13 & 14 & 7 \\
\hline Puerto Rico & Vieques & 3 & 9 & 7 & 14 \\
\hline
\end{tabular}


Table 11. Total number of buildings (all infrastructure types) protected from coastal flooding because of the S05 (structural and ecological over 5-meter width) coral reef restoration scenario for different return-interval storms by region.

\begin{tabular}{|c|c|c|c|c|c|}
\hline \multirow{2}{*}{ Location } & \multirow{2}{*}{ Sublocation } & \multicolumn{4}{|c|}{ Storm Return Interval } \\
\hline & & 10-year & 50-year & 100-year & 500-year \\
\hline Florida & Martin & 10 & 42 & 45 & 19 \\
\hline Florida & Palm Beach & 187 & 880 & 729 & 856 \\
\hline Florida & Broward & 144 & 183 & 397 & 917 \\
\hline Florida & Miami-Dade & 113 & 156 & 296 & 2,154 \\
\hline Florida & Upper Keys & 47 & 37 & 29 & 23 \\
\hline Florida & Middle Keys & 6 & 6 & 1 & 0 \\
\hline Florida & Lower Keys & 52 & 113 & 117 & 193 \\
\hline Puerto Rico & San Juan & 149 & 203 & 346 & 1,181 \\
\hline Puerto Rico & Vega Baja & 110 & 228 & 275 & 530 \\
\hline Puerto Rico & Arecibo & 107 & 263 & 282 & 413 \\
\hline Puerto Rico & Aquadilla & 270 & 579 & 572 & 918 \\
\hline Puerto Rico & Mayaguez & 93 & 215 & 166 & 464 \\
\hline Puerto Rico & Ponce & 25 & 72 & 118 & 103 \\
\hline Puerto Rico & Guayama & 41 & 80 & 94 & 117 \\
\hline Puerto Rico & Humacao & 10 & 16 & 12 & 33 \\
\hline Puerto Rico & Ceiba & 38 & 66 & 41 & 190 \\
\hline Puerto Rico & Culebra & 1 & 13 & 14 & 9 \\
\hline Puerto Rico & Vieques & 2 & 9 & 6 & 13 \\
\hline
\end{tabular}

Table 12. Total value of buildings (all infrastructure types) protected from coastal flooding because of the E25 (ecological over 25-meter width) coral reef restoration scenario for different return-interval storms by region.

[Values in 2010 U.S. dollars]

\begin{tabular}{|c|c|c|c|c|c|}
\hline \multirow{2}{*}{ Location } & \multirow{2}{*}{ Sublocation } & \multicolumn{4}{|c|}{ Storm Return Interval } \\
\hline & & 10-year & 50-year & 100-year & 500 -year \\
\hline Florida & Martin & $\$ 3,677,315$ & $\$ 9,871,480$ & $\$ 10,654,760$ & $\$ 3,686,333$ \\
\hline Florida & Broward & $\$ 55,505,528$ & $\$ 11,780,452$ & $\$ 199,758,766$ & $\$ 367,734,606$ \\
\hline Florida & Miami-Dade & $\$ 49,864,163$ & $\$ 58,761,466$ & $\$ 173,794,630$ & $\$ 644,848,764$ \\
\hline Florida & Middle Keys & $\$ 2,709,543$ & $\$ 3,699,881$ & $\$ 4,210,940$ & $\$ 2,514,855$ \\
\hline Florida & Lower Keys & $\$ 1,629,363$ & $\$ 3,889,530$ & $\$ 8,117,654$ & $\$ 13,113,621$ \\
\hline Puerto Rico & San Juan & $\$ 5,005,778$ & $\$ 11,357,483$ & $\$ 18,565,302$ & $\$ 42,080,502$ \\
\hline Puerto Rico & Vega Baja & $\$ 4,142,689$ & $\$ 13,353,167$ & $\$ 14,432,271$ & $\$ 29,225,960$ \\
\hline Puerto Rico & Arecibo & $\$ 3,164,006$ & $\$ 6,805,721$ & $\$ 9,819,535$ & $\$ 13,210,783$ \\
\hline Puerto Rico & Guayama & $\$ 749,628$ & $\$ 1,416,119$ & $\$ 2,062,639$ & $\$ 3,942,139$ \\
\hline Puerto Rico & Humacao & $\$ 175,982$ & $\$ 325,979$ & $\$ 184,955$ & $\$ 774,414$ \\
\hline Puerto Rico & Ceiba & $\$ 890,305$ & $\$ 3,611,154$ & $\$ 3,303,436$ & $\$ 8,651,369$ \\
\hline Puerto Rico & Culebra & $\$ 24,816$ & $\$ 242,289$ & $\$ 331,699$ & $\$ 243,858$ \\
\hline Puerto Rico & Vieques & $\$ 31,307$ & $\$ 215,219$ & $\$ 113,755$ & $\$ 241,732$ \\
\hline
\end{tabular}


Table 13. Total value of buildings (all infrastructure types) protected from coastal flooding because of the S25 (structural and ecological over 25-meter width) coral reef restoration scenario for different return-interval storms by region.

[Values in 2010 U.S. dollars]

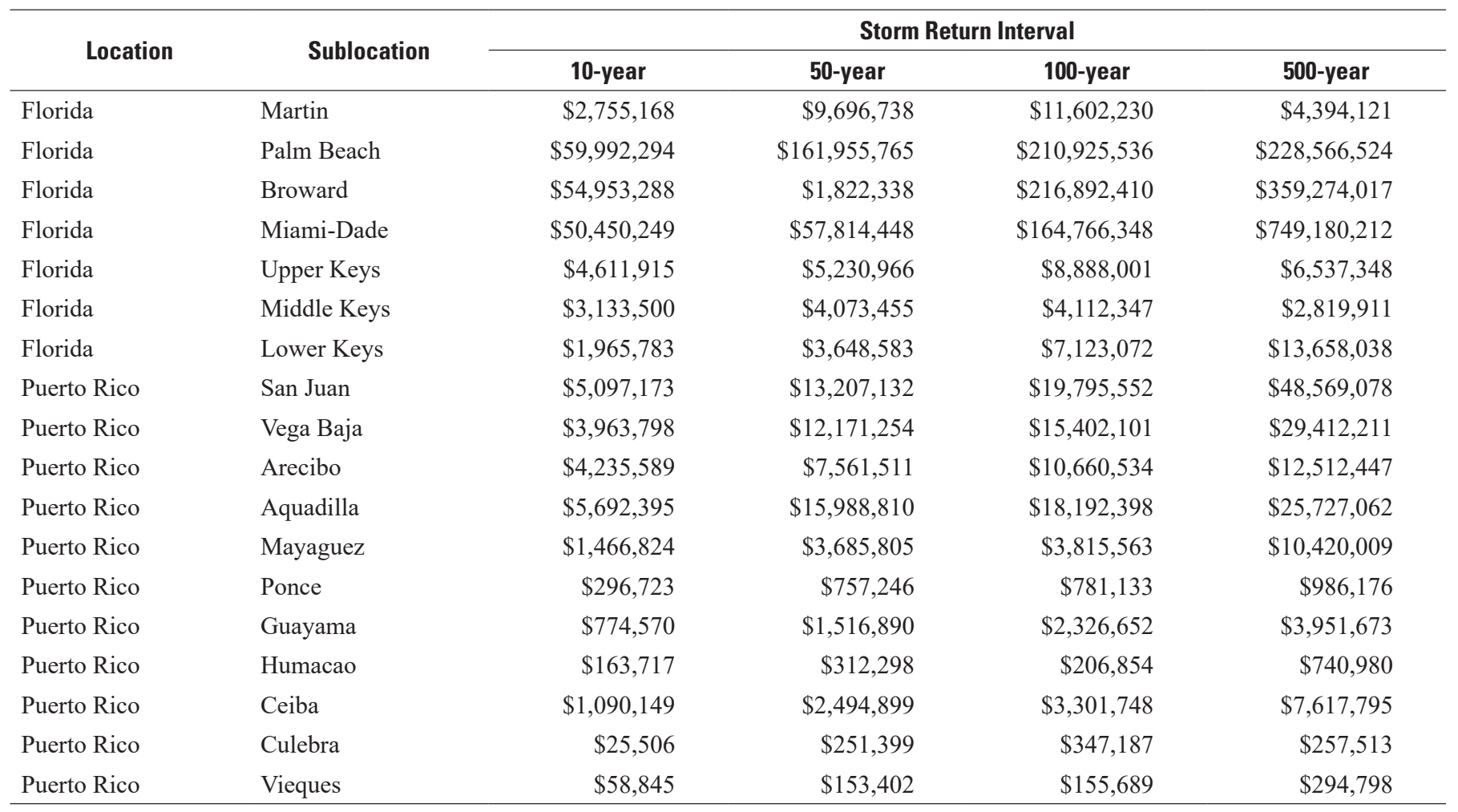

Table 14. Total value of buildings (all infrastructure types) protected from coastal flooding because of the S05 (structural and ecological over 5-meter width) coral reef restoration scenario for different return-interval storms by region.

[Values in 2010 U.S. dollars]

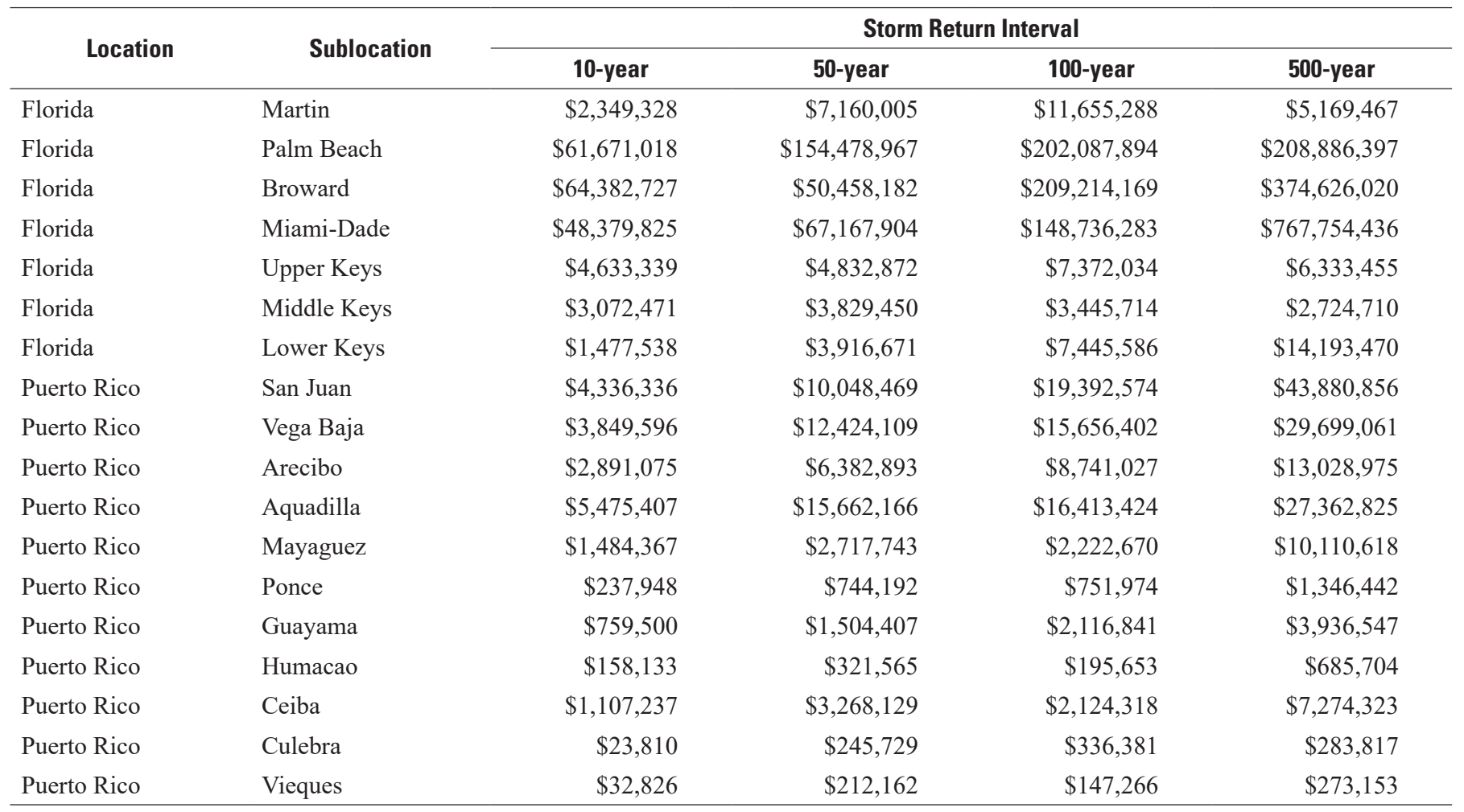




\section{Rigorously Valuing the Impact of Projected Coral Reef Degradation on Coastal Hazard Risk in Florida}

Table 15. Total value of economic activity, in 2010 U.S. dollars, protected from coastal flooding because of the E25 (ecological over 25-meter width) coral reef restoration scenario for different return-interval storms by region.

\begin{tabular}{llrrrr}
\hline \multirow{2}{*}{ Location } & \multicolumn{1}{c}{ Sublocation } & \multicolumn{4}{c}{ Storm Return Interval } \\
\cline { 3 - 5 } & Martin & $\mathbf{1 0}$-year & $\mathbf{5 0}$-year & $\mathbf{1 0 0}$-year & \multicolumn{1}{c}{$\mathbf{5 0 0 \text { -year }}$} \\
\cline { 2 - 5 } Florida & $\$ 1,654,555$ & $\$ 4,647,650$ & $\$ 4,606,686$ & $\$ 1,492,220$ \\
Florida & Palm Beach & $\$ 76,668,351$ & $\$ 140,799,776$ & $\$ 159,748,030$ & $\$ 155,543,098$ \\
Florida & Broward & $\$ 50,089,837$ & $\$ 55,597,166$ & $\$ 170,065,591$ & $\$ 281,985,348$ \\
Florida & Miami-Dade & $\$ 61,803,591$ & $\$ 70,644,332$ & $\$ 193,205,600$ & $\$ 527,302,898$ \\
Florida & Upper Keys & $\$ 4,820,663$ & $\$ 4,334,057$ & $\$ 3,251,322$ & $\$ 2,151,278$ \\
Florida & Middle Keys & $\$ 438,182$ & $\$ 183,933$ & $\$ 328,119$ & $\$ 5,656$ \\
Florida & Lower Keys & $\$ 6,582,299$ & $\$ 14,206,782$ & $\$ 22,400,019$ & $\$ 32,981,639$ \\
Puerto Rico & San Juan & $\$ 14,882,796$ & $\$ 31,820,070$ & $\$ 44,675,758$ & $\$ 117,010,064$ \\
Puerto Rico & Vega Baja & $\$ 4,041,390$ & $\$ 8,633,975$ & $\$ 8,899,939$ & $\$ 21,636,038$ \\
Puerto Rico & Arecibo & $\$ 7,296,059$ & $\$ 18,353,682$ & $\$ 22,705,780$ & $\$ 24,321,715$ \\
Puerto Rico & Aquadilla & $\$ 7,568,579$ & $\$ 27,014,616$ & $\$ 29,835,679$ & $\$ 46,301,760$ \\
Puerto Rico & Mayaguez & $\$ 3,111,006$ & $\$ 14,176,570$ & $\$ 10,478,931$ & $\$ 28,051,175$ \\
Puerto Rico & Ponce & $\$ 1,663,751$ & $\$ 3,174,930$ & $\$ 7,392,365$ & $\$ 4,758,816$ \\
Puerto Rico & Guayama & $\$ 1,393,689$ & $\$ 2,626,615$ & $\$ 3,847,822$ & $\$ 4,883,894$ \\
Puerto Rico & Humacao & $\$ 575,220$ & $\$ 661,369$ & $\$ 547,461$ & $\$ 1,801,379$ \\
Puerto Rico & Ceiba & $\$ 1,227,143$ & $\$ 2,375,098$ & $\$ 2,658,582$ & $\$ 15,612,776$ \\
Puerto Rico & Culebra & $\$ 7,811$ & $\$ 469,760$ & $\$ 490,003$ & $\$ 229,016$ \\
Puerto Rico & Vieques & $\$ 45,634$ & $\$ 255,288$ & $\$ 196,983$ & $\$ 497,100$ \\
\hline
\end{tabular}

Table 16. Total value of economic activity, in 2010 U.S. dollars, protected from coastal flooding because of the S25 (structural and ecological over 25-meter width) coral reef restoration scenario for different return-interval storms by region.

\begin{tabular}{|c|c|c|c|c|c|}
\hline \multirow{2}{*}{ Location } & \multirow{2}{*}{ Sublocation } & \multicolumn{4}{|c|}{ Storm Return Interval } \\
\hline & & 10-year & 50-year & 100-year & 500-year \\
\hline Florida & Martin & $\$ 1,327,729$ & $\$ 4,658,268$ & $\$ 4,980,558$ & $\$ 1,693,587$ \\
\hline Florida & Palm Beach & $\$ 73,061,482$ & $\$ 138,198,870$ & $\$ 161,173,086$ & $\$ 153,951,885$ \\
\hline Florida & Broward & $\$ 47,241,259$ & $\$ 53,229,951$ & $\$ 175,190,655$ & $\$ 274,878,579$ \\
\hline Florida & Miami-Dade & $\$ 63,292,473$ & $\$ 69,579,101$ & $\$ 181,854,423$ & $\$ 606,194,330$ \\
\hline Florida & Upper Keys & $\$ 4,527,984$ & $\$ 4,807,412$ & $\$ 3,717,092$ & $\$ 1,753,327$ \\
\hline Florida & Middle Keys & $\$ 499,823$ & $\$ 375,937$ & $\$ 271,880$ & $\$ 5,656$ \\
\hline Florida & Lower Keys & $\$ 8,252,936$ & $\$ 11,895,455$ & $\$ 18,856,254$ & $\$ 34,743,260$ \\
\hline Puerto Rico & San Juan & $\$ 15,063,262$ & $\$ 36,173,979$ & $\$ 47,580,532$ & $\$ 134,204,819$ \\
\hline Puerto Rico & Vega Baja & $\$ 3,714,478$ & $\$ 8,119,997$ & $\$ 9,891,907$ & $\$ 21,938,396$ \\
\hline Puerto Rico & Arecibo & $\$ 9,842,844$ & $\$ 19,964,997$ & $\$ 25,042,691$ & $\$ 24,692,762$ \\
\hline Puerto Rico & Aquadilla & $\$ 8,406,159$ & $\$ 27,281,572$ & $\$ 31,602,481$ & $\$ 49,176,850$ \\
\hline Puerto Rico & Mayaguez & $\$ 3,370,476$ & $\$ 15,480,118$ & $\$ 18,080,546$ & $\$ 38,379,591$ \\
\hline Puerto Rico & Ponce & $\$ 1,905,911$ & $\$ 4,140,720$ & $\$ 7,686,076$ & $\$ 3,212,151$ \\
\hline Puerto Rico & Guayama & $\$ 1,430,114$ & $\$ 3,042,240$ & $\$ 4,625,564$ & $\$ 4,690,388$ \\
\hline Puerto Rico & Humacao & $\$ 600,378$ & $\$ 649,924$ & $\$ 548,780$ & $\$ 1,991,997$ \\
\hline Puerto Rico & Ceiba & $\$ 1,160,358$ & $\$ 2,327,091$ & $\$ 3,316,940$ & $\$ 11,906,372$ \\
\hline Puerto Rico & Culebra & $\$ 7,633$ & $\$ 472,401$ & $\$ 489,075$ & $\$ 265,272$ \\
\hline Puerto Rico & Vieques & $\$ 102,106$ & $\$ 260,077$ & $\$ 242,540$ & $\$ 529,475$ \\
\hline
\end{tabular}


Table 17. Total value of economic activity, in 2010 U.S. dollars, protected from coastal flooding because of the S05 (structural and ecological over 5-meter width) coral reef restoration scenario for different return-interval storms by region.

\begin{tabular}{llrrrr}
\hline \multirow{2}{*}{ Location } & \multicolumn{1}{c}{ Sublocation } & \multicolumn{4}{c}{ Storm Return Interval } \\
\cline { 3 - 5 } & & \multicolumn{1}{c}{$\mathbf{1 0}$-year } & $\mathbf{5 0}$-year & \multicolumn{1}{c}{$\mathbf{1 0 0 \text { -year }}$} & \multicolumn{1}{c}{$\mathbf{5 0 0}$-year } \\
\hline Florida & Martin & $\$ 1,159,280$ & $\$ 3,563,107$ & $\$ 4,899,608$ & $\$ 1,775,020$ \\
Florida & Palm Beach & $\$ 74,267,934$ & $\$ 134,473,313$ & $\$ 151,544,732$ & $\$ 143,751,943$ \\
Florida & Broward & $\$ 58,898,353$ & $\$ 64,326,875$ & $\$ 170,378,822$ & $\$ 290,650,829$ \\
Florida & Miami-Dade & $\$ 60,469,336$ & $\$ 80,307,184$ & $\$ 151,281,655$ & $\$ 604,356,876$ \\
Florida & Upper Keys & $\$ 5,187,586$ & $\$ 4,117,537$ & $\$ 3,022,845$ & $\$ 1,986,193$ \\
Florida & Middle Keys & $\$ 473,482$ & $\$ 388,558$ & $\$ 189,064$ & $\$ 5,656$ \\
Florida & Lower Keys & $\$ 6,489,797$ & $\$ 13,392,573$ & $\$ 19,669,980$ & $\$ 37,091,404$ \\
Puerto Rico & San Juan & $\$ 12,283,303$ & $\$ 29,181,451$ & $\$ 47,591,729$ & $\$ 118,635,897$ \\
Puerto Rico & Vega Baja & $\$ 3,662,928$ & $\$ 7,932,224$ & $\$ 9,547,361$ & $\$ 21,363,044$ \\
Puerto Rico & Arecibo & $\$ 7,199,702$ & $\$ 17,041,663$ & $\$ 18,422,456$ & $\$ 25,731,158$ \\
Puerto Rico & Aquadilla & $\$ 8,356,061$ & $\$ 26,476,639$ & $\$ 29,509,241$ & $\$ 55,723,458$ \\
Puerto Rico & Mayaguez & $\$ 3,576,180$ & $\$ 12,083,995$ & $\$ 9,839,569$ & $\$ 41,479,291$ \\
Puerto Rico & Ponce & $\$ 1,436,548$ & $\$ 3,933,685$ & $\$ 7,234,450$ & $\$ 5,979,216$ \\
Puerto Rico & Guayama & $\$ 1,470,243$ & $\$ 2,816,478$ & $\$ 3,360,283$ & $\$ 4,736,460$ \\
Puerto Rico & Humacao & $\$ 529,037$ & $\$ 720,742$ & $\$ 580,120$ & $\$ 1,685,301$ \\
Puerto Rico & Ceiba & $\$ 1,232,107$ & $\$ 2,484,910$ & $\$ 2,253,013$ & $\$ 13,604,445$ \\
Puerto Rico & Culebra & $\$ 7,823$ & $\$ 467,339$ & $\$ 484,606$ & $\$ 391,119$ \\
Puerto Rico & Vieques & $\$ 45,636$ & $\$ 238,393$ & $\$ 222,856$ & $\$ 505,736$ \\
\hline
\end{tabular}

Table 18. Annual value protected from coastal flooding because of the E25 (ecological over 25-meter width) coral reef restoration scenario by region.

\begin{tabular}{llccc}
\hline \multicolumn{1}{c}{ Location } & Sublocation & Number of People & Buildings (2010 U.S. dollars) & Economic Activity (2010 U.S. dollars) \\
\hline Florida & Martin & 22 & $\$ 2,356,739$ & $\$ 1,067,305$ \\
Florida & Palm Beach & 910 & $\$ 41,182,328$ & $\$ 45,963,387$ \\
Florida & Broward & 483 & $\$ 30,996,597$ & $\$ 29,704,424$ \\
Florida & Miami-Dade & 723 & $\$ 31,221,253$ & $\$ 37,310,816$ \\
Florida & Upper Keys & 35 & $\$ 1,840,287$ & $\$ 2,595,025$ \\
Florida & Middle Keys & 4 & $\$ 1,542,128$ & $\$ 225,962$ \\
Florida & Lower Keys & 71 & $\$ 1,098,930$ & $\$ 4,198,159$ \\
Puerto Rico & San Juan & 279 & $\$ 3,299,327$ & $\$ 9,594,595$ \\
Puerto Rico & Vega Baja & $\$ 6$ & $\$ 2,877,604$ & $\$ 2,535,453$ \\
Puerto Rico & Arecibo & 177 & $\$ 1,997,839$ & $\$ 4,702,624$ \\
Puerto Rico & Aquadilla & 202 & $\$ 3,507,153$ & $\$ 5,377,990$ \\
Puerto Rico & Mayaguez & $\$ 32,952$ & $\$ 2,368,854$ \\
Puerto Rico & Ponce & 39 & $\$ 183,233$ & $\$ 1,043,676$ \\
Puerto Rico & Guayama & 32 & $\$ 465,376$ & $\$ 855,271$ \\
Puerto Rico & Humacao & 12 & $\$ 105,663$ & $\$ 323,752$ \\
Puerto Rico & Ceiba & 30 & $\$ 663,088$ & $\$ 794,558$ \\
Puerto Rico & Culebra & $\$ 27,023$ & $\$ 30,293$ \\
Puerto Rico & Vieques & 1 & $\$ 27,016$ & $\$ 37,610$ \\
\hline
\end{tabular}




\section{Rigorously Valuing the Impact of Projected Coral Reef Degradation on Coastal Hazard Risk in Florida}

Table 19. Annual value, in number of people or 2010 U.S. dollars, protected from coastal flooding because of the $S 25$ (structural and ecological over 25-meter width) coral reef restoration scenario.

\begin{tabular}{llccc}
\hline \multicolumn{1}{c}{ Location } & Sublocation & Number of People & Buildings (2010 U.S. dollars) & Economic Activity (2010 U.S. dollars) \\
\hline Florida & Martin & 19 & $\$ 1,908,382$ & $\$ 911,809$ \\
Florida & Palm Beach & 871 & $\$ 39,496,829$ & $\$ 44,085,441$ \\
Florida & Broward & 457 & $\$ 30,398,244$ & $\$ 28,219,795$ \\
Florida & Miami-Dade & 739 & $\$ 31,801,890$ & $\$ 38,205,838$ \\
Florida & Upper Keys & 35 & $\$ 2,601,373$ & $\$ 2,475,513$ \\
Florida & Middle Keys & 5 & $\$ 1,767,011$ & $\$ 264,300$ \\
Florida & Lower Keys & 87 & $\$ 1,246,160$ & $\$ 4,887,913$ \\
Puerto Rico & San Juan & 292 & $\$ 3,464,372$ & $\$ 9,973,871$ \\
Puerto Rico & Vega Baja & 89 & $\$ 2,746,235$ & $\$ 2,362,275$ \\
Puerto Rico & Arecibo & 227 & $\$ 2,561,701$ & $\$ 6,045,574$ \\
Puerto Rico & Aquadilla & 220 & $\$ 3,775,410$ & $\$ 5,827,819$ \\
Puerto Rico & Mayaguez & 95 & $\$ 960,625$ & $\$ 2,664,382$ \\
Puerto Rico & Ponce & $\$ 190,445$ & $\$ 1,202,252$ \\
Puerto Rico & Guayama & 45 & $\$ 484,546$ & $\$ 898,048$ \\
Puerto Rico & Humacao & 34 & $\$ 99,100$ & $\$ 336,339$ \\
Puerto Rico & Ceiba & 13 & $\$ 706,630$ & $\$ 750,773$ \\
Puerto Rico & Culebra & 28 & $\$ 27,965$ & $\$ 30,461$ \\
Puerto Rico & Vieques & 1 & $\$ 38,318$ & $\$ 66,036$ \\
\hline
\end{tabular}

Table 20. Annual value, in number of people or 2010 U.S. dollars, protected from coastal flooding because of the S05 (structural and ecological over 5-meter width) coral reef restoration scenario.

\begin{tabular}{llccc}
\hline \multicolumn{1}{c}{ Location } & Sublocation & Number of People & Buildings (2010 U.S. dollars) & Economic Activity (2010 U.S. dollars) \\
\hline Florida & Martin & 16 & $\$ 1,598,947$ & $\$ 779,584$ \\
Florida & Palm Beach & 880 & $\$ 39,824,689$ & $\$ 44,381,497$ \\
Florida & Broward & 524 & $\$ 37,199,586$ & $\$ 34,450,915$ \\
Florida & Miami-Dade & 717 & $\$ 31,138,314$ & $\$ 37,022,760$ \\
Florida & Upper Keys & 38 & $\$ 2,579,497$ & $\$ 2,762,357$ \\
Florida & Middle Keys & 5 & $\$ 1,719,746$ & $\$ 251,216$ \\
Florida & Lower Keys & 69 & $\$ 1,024,028$ & $\$ 4,108,062$ \\
Puerto Rico & San Juan & 243 & $\$ 2,927,043$ & $\$ 8,234,853$ \\
Puerto Rico & Vega Baja & 88 & $\$ 2,705,091$ & $\$ 2,323,163$ \\
Puerto Rico & Arecibo & 171 & $\$ 1,834,642$ & $\$ 4,563,455$ \\
Puerto Rico & Aquadilla & 218 & $\$ 3,644,919$ & $\$ 5,774,396$ \\
Puerto Rico & Mayaguez & 90 & $\$ 910,085$ & $\$ 2,550,581$ \\
Puerto Rico & Ponce & 36 & $\$ 162,237$ & $\$ 969,951$ \\
Puerto Rico & Guayama & 34 & $\$ 474,651$ & $\$ 896,349$ \\
Puerto Rico & Humacao & 11 & $\$ 96,459$ & $\$ 303,624$ \\
Puerto Rico & Ceiba & 30 & $\$ 737,828$ & $\$ 790,248$ \\
Puerto Rico & Culebra & 1 & $\$ 26,888$ & $\$ 30,789$ \\
Puerto Rico & Vieques & 1 & $\$ 28,050$ & $\$ 37,118$ \\
\hline
\end{tabular}




\section{Conclusions}

Here, we apply a new methodology to combine engineering, ecologic, geospatial, social, and economic tools and data to provide a rigorous social and economic valuation of the coastal protection benefits in the State of Florida and the Commonwealth of Puerto Rico gained from the E25, S25, and S05 coral reef restoration scenarios. These analyses help identify where reef restoration might offer the greatest risk reduction benefits. They are not meant to provide designlevel projections of hazard risk reduction benefits. That is, we expect that project proponents could use these results to understand where they would want to design specific kinds of projects. Overall, we expect these values to provide the minimum (or at least low end) estimates of the flood reduction benefits of projects with similar reef restoration height and width characteristics. We expect that in any specific project area that proponents could design projects to achieve even greater flood reduction benefits, such as by putting reefs in shallower water and increasing friction with taller and (or) broader species.

The hazard risk reduction benefits of coral reef restoration are spatially highly variable. In most areas we found little or no benefit from reef restoration (for example, restoration sites were far offshore or relatively deep). However, there were a number of key areas where reef restoration could have substantial benefits for flood risk reduction and could be critical (and cost effective) components of a hazard mitigation strategy. These data make it possible to identify where, when, and how coral reef restoration reduces the storm-induced flooding hazards to Florida and Puerto Rico's coastal communities. The goal is to provide sound, scientific guidance for U.S. Federal, State, Commonwealth, and local governments' efforts on hazard risk reduction and coral reef conservation, restoration, and management by providing rigorous, spatially explicit, highresolution, social and economic valuations of the people and property protected by coral reef restoration to, ultimately, save dollars and protect lives.

\section{Acknowledgments}

This work was carried out by the U.S. Geological Survey (USGS) Coastal and Marine Hazards and Resources Program's Coral Reef Project as part of an effort in the United States and its trust territories to better understand the effect of geologic and oceanographic processes on coral reef systems. This work was supported by U.S. government funding from the 2017 Hurricanes and Wildfire Supplemental. Mike Beck was supported in part by an AXA Research Chair in Coastal Resilience. Any use of trade, firm, or product names is for descriptive purposes only and does not imply endorsement by the U.S. Government.

\section{References Cited}

Bayraktarov, E., Stewart-Sinclair, P.J., Brisbane, S., BoströmEinarsson, L., Saunders, M.I., Lovelock, C.E., Possingham, H.P., Mumby, P.J., and Wilson, K.A., 2019, Motivations, success, and cost of coral reef restoration: Restoration Ecology, v. 27, p. 981-991.

Beck, M.W., and Lange, G.-M., eds., 2016, Guidelines for coastal and marine ecosystem accounting-Incorporating the protective service values of coral reefs and mangroves in national wealth accounts: World Bank, Washington, D.C., $14 \mathrm{p}$.

Booij, N., Ris, R.C., and Holthuijsen, L.H., 1999, A thirdgeneration wave model for coastal regions 1-Model description and validation: Journal of Geophysical Research Oceans, v. 104, p. 7649-7666.

Boström-Einarsson, L., Babcock, R.C., Bayraktarov, E., Ceccarelli, D., Cook, N., Ferse, S.C.A., Hancock, B., Harrison, P., Hein, M., Shaver, E., Smith, A., Suggett, D., Stewart-Sinclair, P.J., Vardi, T., and McLeod, I.M., 2020, Coral restoration-A systematic review of current methods, successes, failures and future directions: PLOS ONE, v. 15, $24 \mathrm{p}$.

Bureau of Economic Analysis, 2018, Gross Domestic Product database, accessed December 6, 2018, at https:/www.bea. gov/data/gdp/gross-domestic-product.

Camus, P., Mendez, F.J., Medina, R., and Cofino, A.S., 2011, Analysis of clustering and selection algorithms for the study of multivariate wave climate: Coastal Engineering, v. 58, no. 6, p. 453-462.

Cangialosi, J.P., Latto, A.S., and Berg, R.J., 2018, Tropical cyclone report-Hurricane Irma: National Hurricane Center, 111 p., accessed December 17, 2018, at https://www.nhc. noaa.gov/data/tcr/AL112017_Irma.pdf.

Carignan, K.S., McLean, S.J., Eakins, B.W., Beasley, L., Love, M.R., and Sutherland, M., 2015, Digital elevation model of Miami, Florida: National Oceanic and Atmospheric Administration, accessed March 9, 2021, at https://data. noaa.gov//metaview/page?xml=NOAA/NESDIS/NGDC/ $\mathrm{MGG} / \mathrm{DEM} /$ iso/xml/5270.xml\&view=getDataView\&heade $\mathrm{r}=$ none.

Chapman, M.G., and Underwood, A.J., 2011, Evaluation of ecological engineering of "armoured" shorelines to improve their value as habitat: Journal of Experimental Marine Biology and Ecology, v. 400, p. 302-313, https://doi. org/10.1016/j.jembe.2011.02.025.

Delft University of Technology, 2016, SWAN website, accessed December 19, 2016, at https://www.tudelft.nl/ en/ceg/over-faculteit/departments/hydraulic-engineering/ sections/environmental-fluid-mechanics/research/swan/. 
Deltares, 2016, XBeach Open Source Community website, accessed December 19, 2016, at http://oss.deltares.nl/web/ xbeach/.

Federal Communications Commission, 2018, 2017 Atlantic hurricane season impact on communications-Report and recommendations: Public Safety and Homeland Security Bureau, Public Safety Docket no. 17-344, accessed December 17, 2018, at https://docs.fcc.gov/public/ attachments/DOC-353805A1.pdf.

Federal Emergency Management Agency, 2016a, Coastal flood risks-Achieving resilience together website, accessed December 19, 2016, at https://www.fema.gov/ coastal-flood-risks-achieving-resilience-together.

Federal Emergency Management Agency, 2016b, FEMA flood map service center-Hazus: Federal Emergency Management Agency, accessed December 19, 2016, at https://msc.fema.gov/portal/resources/hazus.

Federal Emergency Management Agency, 2018, Hazus multi-hazard loss estimation methodology, flood model: Hazus ${ }^{\circledR}-M H$ MR3 technical manual, 471 p., accessed February 22, 2018, at https://www.fema. gov/plan/prevent/hazus. [Document moved by time of publication; accessed March 5, 2019, at https://www.hsdl. org/?abstract\&did=480580.]

Ferrario, F., Beck, M.W., Storlazzi, C.D., Micheli, F., Shepard, C.C., and Airoldi, L., 2014, The effectiveness of coral reefs for coastal hazard risk reduction and adaptation: Nature Communications, v. 5, 9 p.

Florida Fish and Wildlife Conservation Commission, 2016, Unified Florida coral reef tract map version 2.0: Fish and Wildlife Research Institute, accessed September 17, 2017, at http:/ocean.floridamarine.org/IntegratedReefMap/ UnifiedReefTract.htm.

Fox, H.E., Mous, P.J., Pet, J.S., Muljadi, A.H., and Caldwell, R.L., 2005, Experimental assessment of coral reef rehabilitation following blast fishing: Conservation Biology, v. 19 , p. $98-107$.

Gardner, T.A., Cote, I.M., Gill, J.A., Grant, A., and Watkinson, A.R., 2005, Hurricanes and Caribbean coral reefs-Impacts, recovery patterns, and role in long-term decline: Ecology, v. 86, p. $174-184$.

Grinsted, A., Moore, J.C., and Jevrejeva, S., 2010, Reconstructing sea level from paleo and projected temperatures 200 to 2100 AD: Climate Dynamics, v. 34, p. 461-472.

Grothe, P.R., Taylor, L.A., Eakins, B.W., Carignan, K.S., Friday, D.Z., Lim, E., and Love, M.R., 2011, Key West, Florida 1/3 arc-second MHW coastal digital elevation model: National Oceanic and Atmospheric Administration, accessed on March 9, 2021, at https://data.noaa.gov// metaview/page?xml=NOAA/NESDIS/NGDC/MGG/DEM/ iso/xml/431.xml\&view=getDataView\&header=none.
Haisfield, K.M., Fox, H.E., Yen, S., Mangubhai, S., and Mous, P.J., 2010, An ounce of prevention-Cost-effectiveness of coral reef rehabilitation relative to enforcement: Conservation Letters, v. 3, p. 243-250.

Hallegatte, S., Green, C., Nicholls, R.J., and Corfee-Morlot, J., 2013, Future flood losses in major coastal cities: Nature Climate Change, v. 3, p. 802-806.

Heron, S., Morgan, J., Eakin, C.M., and Skirving, W., 2008, Hurricanes and their effects on coral reefs, in Wilkinson, C., and Souter, D., Status of Caribbean coral reefs after bleaching and hurricanes in 2005: Global Coral Reef Monitoring Network, Reef and Rainforest Research Centre, p. 31-36.

Hinkel, J., Lincke, D., Vafeidis, A.T., Perrette, M., Nicholls, R.J., Tol, R.S.J., Marzeion, B., Fettweis, X., Ionescu, C., and Levermann, A., 2014, Coastal flood damage and adaptation costs under 21 st century sea-level rise: Proceedings of the National Academy of Sciences, v. 111, no. 9, p. 3292-3297.

Hoeke, R.K., Storlazzi, C.D., and Ridd, P.V., 2011, Hydrodynamics of a bathymetrically complex fringing coral reef embayment-Wave climate, in situ observations, and wave prediction: Journal of Geophysical Research Oceans, v. 166,19 p.

Kopp, R.E., Horton, R.M., Little, C.M., Mitrovica, J.X., Oppenheimer, M., Rasmussen, D.J., Strauss, B.H., and Tebaldi, C., 2014, Probabilistic 21st and 22nd century sealevel projections at a global network of tide-gauge sites: Earth's Future, v. 2, p. 383-406.

Ladd, M.C., Miller, M.W., Hunt, J.H., Sharp, W.C., and Burkepile, D.E., 2018, Harnessing ecological processes to facilitate coral restoration: Frontiers in Ecology and the Environment, v. 16, 239-247.

Lirman, D., and Schopmeyer, S., 2016, Ecological solutions to reef degradation-Optimizing coral reef restoration in the Caribbean and Western Atlantic: PeerJ, v. 4, 19 p.

Lugo, A.E., Rogers, C.S., and Nixon, S.W., 2000, Hurricanes, coral reefs and rainforests - Resistance, ruin and recovery in the Caribbean: AMBIO-A Journal of the Human Environment, v. 29, p. 106-115.

McCreless, E., and Beck, M.W., 2016, Rethinking our global coastal investment portfolio: Journal of Ocean and Coastal Economics, v. 3, no. 6, 19 p.

Méndez, F.J., Menéndez, M., Luceño, A., and Losada, I.J., 2006, Estimation of the long-term variability of extreme significant wave height using a time-dependent Peak Over Threshold (POT) model: Journal of Geophysical Research Oceans, v. 111, 13 p. 
Menéndez, M., and Woodworth, P.L., 2010, Changes in extreme high water levels based on a quasi-global tidegauge data set: Journal of Geophysical Research Oceans, v. $115,15 \mathrm{p}$.

Montoya-Maya, P.H., Smit, K.P., Burt, A.J., and Frias-Torres, S., 2016, Large-scale coral reef restoration could assist natural recovery in Seychelles, Indian Ocean: Nature Conservation, v. 16, p. 1-17.

National Geophysical Data Center, 2001, U.S. coastal relief model - Florida and East Gulf of Mexico: National Oceanic and Atmospheric Administration National Geophysical Data Center, accessed December 19, 2016, at https://doi. org/10.7289/V5W66HPP.

National Oceanic and Atmospheric Administration, 2001, Benthic habitats of Puerto Rico: National Oceanic and Atmospheric Administration Coastal Services Center, accessed September 17, 2017, at https://products. coastalscience.noaa.gov/collections/benthic/e95usvi_pr/ default.aspx.

National Oceanic and Atmospheric Administration, 2015, Electronic navigational charts: National Oceanic and Atmospheric Administration Office of Coast Survey, accessed March 10, 2021, at https://www.nauticalcharts. noaa.gov/charts/noaa-enc.html.

National Oceanic and Atmospheric Administration, 2017, Extreme water levels-Annual exceedance probability curves, accessed December 19, 2016, at https:// tidesandcurrents.noaa.gov/est/.

National Research Council, 2014, Reducing coastal risks on the East and Gulf Coasts: The National Academies Press, Washington, D.C., 208 p., https://doi.org/10.17226/18811.

National Science and Technology Council, 2015, Ecosystemservice assessment-Research needs for coastal green infrastructure: Office of Science and Technology Policy, $40 \mathrm{p}$.

Neumann, B., Vafeidis, A.T., Zimmermann, J., and Nicholls, R.J., 2015, Future coastal population growth and exposure to sea-level rise and coastal flooding - A global assessment: PLOS ONE, v. 10, no. 3, 34 p., https://doi.org/10.1371/ journal.pone. 0118571 .

Olsen, A.S., Zhou, Q., Linde, J.J., and Arnbjerg-Nielsen, K., 2015, Comparing methods of calculating expected annual damage in urban pluvial flood risk assessments: Water, v. 7, p. $255-270$.

Pasch, R.J., Penny, A.B., and Berg, R., 2018, Tropical cyclone report-Hurricane Maria: National Hurricane Center, 48 p., accessed December 17, 2018, at https://www.nhc.noaa.gov/ data/tcr/AL152017_Maria.pdf.
Pomeroy, A., Lowe, R.J., Symonds, G., van Dongeren, A.R., and Moore, C., 2012, The dynamics of infragravity wave transformation over a fringing reef: Journal of Geophysical Research, v. 117, 17 p.

Quataert, E., Storlazzi, C.D., van Rooijen, A., Cheriton, O.M., and van Dongeren, A.R., 2015, The influence of coral reefs and climate change on wave-driven flooding of tropical coastlines: Geophysical Research Letters, v. 42, no. 15, p. 6407-6415.

Reguero, B.G., Beck, M.W., Agostini, V.N., Kramer, P., and Hancock, B., 2018, Coral reefs for coastal protection-A new methodological approach and engineering case study in Grenada: Journal of Environmental Management, v. 210, p. 146-161.

Reguero, B.G., Menéndez, M., Méndez, F.J., Mínguez, R., and Losada, I.J., 2012, A Global Ocean Wave (GOW) calibrated reanalysis from 1948 onwards: Coastal Engineering, v. 65, p. $38-55$.

Rinkevich, B., 2015, Climate change and active reef restoration-Ways of constructing the "reefs of tomorrow": Journal of Marine Science and Engineering, v. 3, p. 111-127.

Ris, R.C., Holthuijsen, L.H., and Booij, N., 1999, A thirdgeneration wave model for coastal regions - Part 2Verification: Journal of Geophysical Research Oceans, v. 104 , no. C4, p. $7667-7681$.

Roelvink, D., Reniers, A., van Dongeren, A.R., van Thiel de Vries, J., McCall, R. and Lescinski, J., 2009, Modelling storm impacts on beaches, dunes and barrier islands: Coastal Engineering, v. 56, p. 1133-1152.

Rogers, C.S., 1993, Hurricanes and coral reefs-The intermediate disturbance hypothesis revisited: Coral Reef, v. 12 , p. $127-137$.

Scawthorn, C., Blais, N., Seligson, H., Tate, E., Mifflin, E., Thomas, W., Murphy, J., and Jones, C., 2006a, HAZUS-MH flood loss estimation methodology I-Overview and flood hazard characterization: Natural Hazards Review, v. 7, p. $60-71$.

Scawthorn, C., Flores, P., Blais, N., Seligson, H., Tate, E., Chang, S., Mifflin, E., Thomas, W., Murphy, J., Jones, C., and Lawrence, M., 2006b, HAZUS-MH flood loss estimation methodology II—Damage and loss assessment: Natural Hazards Review, v. 7, p. 72-81.

Scoffin, T.P., 1993, The geological effects of hurricanes on coral reefs and the interpretation of storm deposits: Coral Reefs, v. 12, p. 203-221.

Shaver, E.C., and Silliman, B.R., 2017, Time to cash in on positive interactions for coral restoration: PeerJ, v. 5, 20 p. 
Sheppard, C., Dixon, D.J., Gourlay, M., Sheppard, A., and Payet, R., 2005, Coral mortality increases wave energy reaching shores protected by reef flats-Examples from the Seychelles: Estuarine, Coastal and Shelf Science, v. 64, p. 223-234.

Storlazzi, C.D., Elias, E.P.L., and Berkowitz, P., 2015, Many atolls may be uninhabitable within decades due to climate change: Scientific Reports, v. 5, no. 14546, 9 p.

Storlazzi, C.D., Gingerich, S.B., van Dongeren, A.R., Cheriton, O.M., Swarzenski, P.W., Quataert, E., Voss, C.I., Field D.W., Annamalai, H., Piniak G.A., and McCall, R., 2018, Most atolls will be uninhabitable by the mid-21st century because of sea-level rise exacerbating wave-driven flooding: Science Advances, v. 4, https://doi.org/10.1126/ sciadv.aap9741.

Storlazzi, C.D., Reguero, B.G., Cole, A.D., Lowe, E., Shope, J.B., Gibbs, A.E., Nickel, B.A., McCall, R.T., van Dongeren, A.R., and Beck, M.W., 2019, Rigorously valuing the role of U.S. coral reefs in coastal hazard risk reduction: U.S. Geological Survey Open-File Report 2019-1027, 42 p., https://doi.org/10.3133/ofr20191027.

Taebi, S., and Pattiaratchi, C., 2014, Hydrodynamic response of a fringing coral reef to a rise in mean sea level: Ocean Dynamics, v. 64, no. 7, p. 975-987.

Taylor, L.A., Eakins, B.W., Carignan, K.S., Warnken, R.R., Sazonova, T., and Schoolcraft, D.C., 2008a, Puerto Rico coastal digital elevation model: National Oceanic and Atmospheric Adiministration Technical Memorandum NESDIS NGDC-13, accessed December 19, 2016, at https://www.ngdc.noaa.gov/dem/squareCellGrid/ download/1561. [Data moved by time of publication; accessed March 4, 2019, at https://data.noaa.gov//metaview/ page?xml=NOAA/NESDIS/NGDC/MGG/DEM/iso/ $\mathrm{xml} / 1561 . x m l \& v i e w=$ getDataView\&header=none.]

Taylor, L.A., Eakins, B.W., Carignan, K.S., Warnken, R.R., Sazonova, T., and Schoolcraft, D.C., 2008b, Arecibo, Puerto Rico coastal digital elevation model: National Oceanic and Atmospheric Administration Technical Memorandum NESDIS NGDC-13, accessed December 19, 2016, at https://www.ngdc.noaa.gov/dem/squareCellGrid/ download/393. [Data moved by time of publication; accessed March 4, 2019, at https://data.noaa.gov//metaview/ page?xml=NOAA/NESDIS/NGDC/MGG/DEM/iso/ $\mathrm{xml} / 393 . \mathrm{xml} \& \mathrm{view}=$ getDataView\&header=none.]

Taylor, L.A., Eakins, B.W., Carignan, K.S., Warnken, R.R., Sazonova, T., and Schoolcraft, D.C., 2008c, Fajardo, Puerto Rico 1/3 arc-second MHW coastal digital elevation model: National Oceanic and Atmospheric Administration Technical Memorandum NESDIS NGDC-13, accessed December 19, 2016 at https://www.ngdc.noaa.gov/dem/ squareCellGrid/download/689. [Data moved by time of publication; accessed March 5, 2019, at https://data.noaa. gov//metaview/page?xml=NOAA/NESDIS/NGDC/MGG/ DEM/iso/xml/689.xml\&view=getDataView\&header=none.]
Taylor, L.A., Eakins, B.W., Carignan, K.S., Warnken, R.R., Sazonova, T., and Schoolcraft, D.C., 2008d, Guayama, Puerto Rico 1/3 arc-second MHW coastal digital elevation model: National Oceanic and Atmospheric Administration Technical Memorandum NESDIS NGDC-13, accessed December 19, 2016, at https:/www.ngdc.noaa.gov/dem/ squareCellGrid/download/691. [Data moved by time of publication; accessed March 5, 2019, at https://data.noaa. gov//metaview/page?xml=NOAA/NESDIS/NGDC/MGG/ $\mathrm{DEM} / \mathrm{iso} / \mathrm{xml} / 691 . \mathrm{xml} \& v i e w=$ getDataView\&header=none.]

Taylor, L.A., Eakins, B.W., Carignan, K.S., Warnken, R.R., Sazonova, T., and Schoolcraft, D.C., 2008e, Mayaguez, Puerto Rico 1/3 arc-second MHW coastal digital elevation model 2007: National Oceanic and Atmospheric Administration Technical Memorandum NESDIS NGDC13, accessed December 19, 2016, at https://www.ngdc.noaa. gov/dem/squareCellGrid/download/1541. [Data moved by time of publication; accessed March 5, 2019, at https://data. noaa.gov//metaview/page?xml=NOAA/NESDIS/NGDC/ MGG/DEM/iso/xml/1541.xml\&view=getDataView\&heade $\mathrm{r}=$ none.]

Taylor, L.A., Eakins, B.W., Carignan, K.S., Warnken, R.R., Sazonova, T., and Schoolcraft, D.C., 2008f, Ponce, Puerto Rico 1/3 arc-second MHW coastal digital elevation model: National Oceanic and Atmospheric Administration Technical Memorandum NESDIS NGDC-13, accessed December 19, 2016, at https://www.ngdc.noaa.gov/dem/ squareCellGrid/download/391. [Data moved by time of publication; accessed March 5, 2019, at https://data.noaa. gov//metaview/page?xml=NOAA/NESDIS/NGDC/MGG/ $\mathrm{DEM} /$ iso/xml/391.xml\&view=getDataView\&header=none.]

Taylor, L.A., Eakins, B.W., Carignan, K.S., Warnken, R.R., Sazonova, T., and Schoolcraft, D.C., 2008g, San Juan, Puerto Rico coastal digital elevation model: National Oceanic and Atmospheric Administration Technical Memorandum NESDIS NGDC-13, accessed December 19, 2016, at https://www.ngdc.noaa.gov/dem/squareCellGrid/ download/1601. [Data moved by time of publication; accessed March 5, 2019, at https://data.noaa.gov//metaview/ page? $\mathrm{xml}=\mathrm{NOAA} / \mathrm{NESDIS} / \mathrm{NGDC} / \mathrm{MGG} / \mathrm{DEM} / \mathrm{iso} /$ $\mathrm{xml} / 1601 . \mathrm{xml} \& \mathrm{view}=$ getDataView\&header=none.]

Thieler, E.R., Himmelstoss, E.A., Zichichi, J.L., and Ergul, A., 2009, The Digital Shoreline Analysis System (DSAS) version 4.0-An ArcGIS extension for calculating shoreline change: U.S. Geological Survey Open-File Report 20081278, https://doi.org/10.3133/ofr20081278.

United Nations, 2016, World Population Prospects 2016 database, accessed December 19, 2016, at https://esa.un.org/ unpd/wpp/.

U.S. Census Bureau, 2016, TIGER products database, accessed December 19, 2016, at https://www.census.gov/ geo/maps-data/data/tiger.html. 
U.S. Census Bureau, 2018, 2010 Statistics of U.S. businesses (SUSB) annual datasets by establishment industry: U.S. Census Bureau online database, accessed February 22, 2018, at https://www.census.gov/data/tables/2010/econ/ susb/2010-susb-annual.html.

van Dongeren, A.R., Lowe, R.J., Pomeroy, A., Trang, D.M., Roelvink, D., Symonds, G., and Ranasinghe, R., 2013, Numerical modeling of low-frequency wave dynamics over a fringing coral reef: Coastal Engineering, v. 73, p. 178-190.

van Zanten, B.T., van Beukering, P.J.H., and Wagtendonk, A.J., 2014, Coastal protection by coral reefs-A framework for spatial assessment and economic valuation: Ocean and Coastal Management, v. 96, p. 94-103.

Vermeer, M., and Rahmstorf, S., 2009, Global sea level linked to global temperature: Proceedings of the National Academy of Sciences, v. 106, no. 51, p. 21,527-21,532.

Wood, N.J., Ratliff, J., and Peters, J., 2013, Community exposure to tsunami hazards in California: U.S. Geological Survey Scientific Investigations Report 2012-5222, 49 p.

\section{Additional Digital Information}

The digital data used to produce this report can be found here: https://doi.org/10.5066/P9ZQKZR9
For an online portable document format (PDF) version of this report, visit https://doi.org/10.3133/ofr20211054

For more information on the U.S. Geological Survey's Coral Reef Project, visit http://coralreefs.wr.usgs.gov/

For more information on the U.S. Geological Survey Coastal and Marine Program's Coastal Change Hazards portal, visit https://marine.usgs.gov/coastalchangehazardsportal/

For more information on the University of California at Santa Cruz's Coastal Resilience Laboratory, visit https://www.coastalresiliencelab.org/

For more information on the University of California at Santa Cruz's Center for Integrated Spatial Research, visit http://spatial.cisr.ucsc.edu/

For more information on NOAA National Centers for Coastal Ocean Science, visit https://coastalscience.noaa.gov/

\section{Direct Contact Information}

Regarding this report, contact Curt D. Storlazzi (USGS Coral Reef Project Chief) at cstorlazzi@usgs.gov 

Appendixes 1-6 


\section{Appendix 1. SWAN Model Settings}

\begin{tabular}{|c|c|}
\hline Parameter & Value \\
\hline \multicolumn{2}{|c|}{ General } \\
\hline OnlyInputVerify & false \\
\hline SimMode & stationary \\
\hline DirConvention & nautical \\
\hline WindSpeed & $0.0000000 \mathrm{e}+000$ \\
\hline WindDir & $0.0000000 \mathrm{e}+000$ \\
\hline \multicolumn{2}{|c|}{ Processes } \\
\hline GenModePhys & 3 \\
\hline Breaking & true \\
\hline BreakAlpha & $1.0000000 \mathrm{e}+000$ \\
\hline BreakGamma & $7.3000002 \mathrm{e}-001$ \\
\hline Triads & false \\
\hline TriadsAlpha & $1.0000000 \mathrm{e}-001$ \\
\hline TriadsBeta & $2.2000000 \mathrm{e}+000$ \\
\hline WaveSetup & false \\
\hline BedFriction & jonswap \\
\hline BedFricCoef & $6.7000002 \mathrm{e}-002$ \\
\hline Diffraction & true \\
\hline DiffracCoef & $2.0000000 \mathrm{e}-001$ \\
\hline DiffracSteps & 5 \\
\hline DiffracProp & true \\
\hline WindGrowth & false \\
\hline WhiteCapping & Komen \\
\hline Quadruplets & false \\
\hline Refraction & true \\
\hline FreqShift & true \\
\hline WaveForces & dissipation $3 \mathrm{~d}$ \\
\hline \multicolumn{2}{|c|}{ Numerics } \\
\hline DirSpaceCDD & $5.0000000 \mathrm{e}-001$ \\
\hline
\end{tabular}

\begin{tabular}{|c|c|}
\hline Parameter & Value \\
\hline FreqSpaceCSS & $5.0000000 \mathrm{e}-001$ \\
\hline RChHsTm01 & $2.0000000 \mathrm{e}-002$ \\
\hline RChMeanHs & $2.0000000 \mathrm{e}-002$ \\
\hline RChMeanTm01 & $2.0000000 \mathrm{e}-002$ \\
\hline PercWet & $9.8000000 \mathrm{e}+001$ \\
\hline MaxIter & 100 \\
\hline \multicolumn{2}{|c|}{ Output } \\
\hline TestOutputLevel & 0 \\
\hline TraceCalls & false \\
\hline UseHotFile & false \\
\hline WriteCOM & false \\
\hline \multicolumn{2}{|c|}{ Domain } \\
\hline DirSpace & circle \\
\hline NDir & 72 \\
\hline StartDir & $0.0000000 \mathrm{e}+000$ \\
\hline EndDir & $0.0000000 \mathrm{e}+000$ \\
\hline FreqMin & $5.0000001 \mathrm{e}-002$ \\
\hline FreqMax & $1.0000000 \mathrm{e}+000$ \\
\hline NFreq & 24 \\
\hline Output & true \\
\hline \multicolumn{2}{|c|}{ Boundary } \\
\hline Definition & orientation \\
\hline SpectrumSpec & parametric \\
\hline SpShapeType & jonswap \\
\hline PeriodType & peak \\
\hline DirSpreadType & power \\
\hline PeakEnhanceFac & $=3.3000000 \mathrm{e}+000$ \\
\hline GaussSpread & $9.9999998 \mathrm{e}-003$ \\
\hline
\end{tabular}




\section{Appendix 2. SWAN Model Grid Information}

[km, kilometer; m, meter; NGDC, National Geophysical Data Center; PR, Puerto Rico, -, no data]

\begin{tabular}{lllll}
\hline \multicolumn{1}{c}{ Location } & $\mathbf{1 - k m}$ grid cells & \multicolumn{1}{c}{ 200-m grid cells } & Grid dimensions (E-W x N-S) & Data source \\
\hline Florida & - & Dry Tortugas & $295 \times 190$ & NGDC, 2001 \\
Florida & - & Key West & $505 \times 255$ & NGDC, 2001 \\
Florida & - & Marathon & $505 \times 337$ & NGDC, 2001 \\
Florida & - & Islamorada & $383 \times 334$ & NGDC, 2001 \\
Florida & - & Miami & $291 \times 502$ & NGDC, 2001 \\
Puerto Rico & - & PR_North-Central & $245 \times 94$ & Taylor and others, 2008a \\
Puerto Rico & - & PR_Northeast & $330 \times 155$ & Taylor and others, 2008a \\
Puerto Rico & - & PR_Northwest & $330 \times 155$ & Taylor and others, 2008a \\
Puerto Rico & - & PR_South-Central & $315 \times 155$ & Taylor and others, 2008a \\
Puerto Rico & - & PR_Southeast & $320 \times 160$ & Taylor and others, 2008a \\
Puerto Rico & - & PR_Southwest & $320 \times 165$ & Taylor and others, 2008a \\
Puerto Rico & & $230 \times 160$ & Taylor and others, 2008a \\
\hline
\end{tabular}

\section{Appendix 3. Benthic Habitat and Shoreline Datasets}

[FFWCC, Florida Fish and Wildlife Conservation Commission; NOAA, National Oceanic and Atmospheric Administration]

\begin{tabular}{|c|c|c|c|c|}
\hline \multirow{2}{*}{ Location } & \multirow{2}{*}{ Sublocation } & \multicolumn{2}{|c|}{ Benthic habitat data } & \multirow{2}{*}{ Shoreline data source } \\
\hline & & Minimum mapping unit & Data source & \\
\hline Florida & Dry Tortugas & $<1$ acre & FFWCC 2016 & NOAA, 2015 \\
\hline Florida & Keys & $<1$ acre & FFWCC 2016 & NOAA, 2015 \\
\hline Florida & Miami & $<1$ acre & FFWCC 2016 & NOAA, 2015 \\
\hline Puerto Rico & Puerto Rico & 1 acre & NOAA, 2001 & NOAA, 2015 \\
\hline Puerto Rico & Culebra & 1 acre & NOAA, 2001 & NOAA, 2015 \\
\hline Puerto Rico & Vieques & 1 acre & NOAA, 2001 & NOAA, 2015 \\
\hline
\end{tabular}




\section{Appendix 4. Cross-shore XBeach Transects}

\begin{tabular}{llc}
\hline \multicolumn{1}{c}{ Location } & \multicolumn{1}{c}{ Sublocation } & Number of cross-shore transects \\
\hline Florida & Dry Tortugas & 300 \\
Florida & Key West & 545 \\
Florida & Keys & 1,127 \\
Florida & Miami & 1,139 \\
Florida & Palm Beach & 1,168 \\
Puerto Rico & Puerto Rico & 4,588 \\
Puerto Rico & Culebra & 244 \\
Puerto Rico & Vieques & 687 \\
\hline
\end{tabular}

\section{Appendix 5. Bathymetric Datasets}

[NGDC, National Geophysical Data Center]

\begin{tabular}{lll}
\hline \multicolumn{1}{c}{ Location } & \multicolumn{1}{c}{ Sublocation } & \multicolumn{1}{c}{ Data Source } \\
\hline Florida & Dry Tortugas & NGDC, 2001 \\
Florida & Key West & Grothe and others, 2011 \\
Florida & Florida Keys & NGDC, 2001 \\
Florida & Miami & Carignan and others, 2015 \\
Florida & Palm Beach & NGDC, 2001 \\
Puerto Rico & Arecibo & Taylor and others, 2008b \\
Puerto Rico & Culebra & Taylor and others, 2008a \\
Puerto Rico & Fajardo & Taylor and others, 2008c \\
Puerto Rico & Guayama & Taylor and others, 2008d \\
Puerto Rico & Mayaguez & Taylor and others, 2008e \\
Puerto Rico & Ponce & Taylor and others, 2008f \\
Puerto Rico & San Juan & Taylor and others, 2008g \\
Puerto Rico & Vieques & Taylor and others, 2008a \\
\hline
\end{tabular}




\section{Appendix 6. XBeach Model Settings}

\begin{tabular}{|c|c|c|}
\hline Category & Parameter & Value \\
\hline \multirow[t]{4}{*}{ Flow boundary condition parameters } & front & abs_1d \\
\hline & left & wall \\
\hline & right & wall \\
\hline & back & wall \\
\hline \multirow[t]{2}{*}{ Flow } & bedfriction & chezy \\
\hline & bedfricfile & fric.txt \\
\hline \multirow[t]{3}{*}{ Grid parameters } & thetamin & -60 \\
\hline & thetamax & 60 \\
\hline & dtheta & 10 \\
\hline Model time & tstop & 3,600 \\
\hline Tide boundary conditions & tideloc & 1 \\
\hline \multirow[t]{2}{*}{ Wave boundary condition parameters } & instat & jons \\
\hline & $\operatorname{dir} 0$ & 270 \\
\hline \multirow[t]{6}{*}{ Output variables } & outputformat & netcdf \\
\hline & rugdepth & 0.020000 \\
\hline & tintm & 3,500 \\
\hline & tintp & 10 \\
\hline & tintg & 3,100 \\
\hline & tstart & 100 \\
\hline \multirow[t]{11}{*}{ Output options } & nglobalvar & 4 \\
\hline & $\mathrm{H}$ & - \\
\hline & $\mathrm{zs}$ & - \\
\hline & $\mathrm{zb}$ & - \\
\hline & $\mathrm{E}$ & - \\
\hline & nmeanvar & 3 \\
\hline & $\mathrm{H}$ & - \\
\hline & zs & - \\
\hline & $\mathrm{zb}$ & - \\
\hline & npoints & 1 \\
\hline & nrugauge & 1 \\
\hline
\end{tabular}


Moffett Field Publishing Service Center, California Manuscript approved for publication May 6, 2021 Edited by John Mark Brigham

Layout and design by Kimber Petersen

Cartography and illustration support by JoJo Mangano 
